\title{
Cataloging the potential SNPs (single nucleotide polymorphisms) associated with quantitative traits, viz. BMI (body mass index), IQ (intelligence quotient) and BP (blood pressure): an updated review
}

\author{
Waseem Chauhan, Rafat Fatma, Afiya Wahab and Mohammad Afzal ${ }^{*}$
}

\begin{abstract}
Background: Single nucleotide polymorphism (SNP) variants are abundant, persistent and widely distributed across the genome and are frequently linked to the development of genetic diseases. Identifying SNPs that underpin complex diseases can aid scientists in the discovery of disease-related genes by allowing for early detection, effective medication and eventually disease prevention.

Main body: Various SNP or polymorphism-based studies were used to categorize different SNPs potentially related to three quantitative traits: body mass index (BMI), intelligence quotient $(\mathrm{IQ})$ and blood pressure, and then uncovered common SNPs for these three traits. We employed SNPedia, RefSNP Report, GWAS Catalog, Gene Cards (Data Bases), PubMed and Google Scholar search engines to find relevant material on SNPs associated with three quantitative traits. As a result, we detected three common SNPs for all three quantitative traits in global populations: SNP rs6265 of the BDNF gene on chromosome 11p14.1, SNP rs131070325 of the SL39A8 gene on chromosome 4p24 and SNP rs4680 of the COMT gene on chromosome 22q11.21.

Conclusion: In our review, we focused on the prevalent SNPs and gene expression activities that influence these three quantitative traits. These SNPs have been used to detect and map complex, common illnesses in communities for homogeneity testing and pharmacogenetic studies. High blood pressure, diabetes and heart disease, as well as BMI, schizophrenia and IQ, can all be predicted using common SNPs. Finally, the results of our work can be used to find common SNPs and genes that regulate these three quantitative features across the genome.
\end{abstract}

Keywords: SNPs, Polymorphisms, Quantitative traits, dbSNP, SNPedia, BMI, IQ, BP

\section{Background}

In the presence of an environmental stimulus, genetic differences arise within and between populations, resulting in polymorphisms that can be connected to a hereditary trait or phenotype. SNPs (pronounced "snips"), or

*Correspondence: ma.afzal1235@gmail.com; afzal1235@rediffmail.com Human Genetics and Toxicology Laboratory, Section of Genetics, Department of Zoology, Aligarh Muslim University, Aligarh 202002, India single nucleotide polymorphisms, are the most frequent type of DNA sequence variation detected in people. Each SNP refers to a change in a single nucleotide, which is a DNA building unit. SNPs occur naturally in everyone's DNA and are found around every 300-2000 base pairs across the genome [1]. On average, there are 84.7 million single nucleotide polymorphisms (SNPs) in the human genome [2], including both coding and non-coding regions of the genes. SNPs can be used as biological 
markers to assist researchers in finding out genes linked to disease. Regulatory SNPs are oligonucleotide substitutions that occur in regulatory regions and control gene expression. SNPs found within a gene or in a regulatory region around a gene may thus have a direct effect on the condition by altering the gene's function. In general, these SNPs are linked to complex traits, which can represent unique characteristics of an organism or an individual $[1,3]$. Moreover, genes, environment and their interactions can influence these traits. Genetically, all traits are divided into two categories based on their effect on an organism's phenotype, i.e., qualitative and quantitative. Quantitative traits (QTs aka complex traits) are phenotypic traits that are determined by a large number of small-effect genes in combination with the environment, e.g., crop yield, plant disease resistance, diabetes, skin color, weight gain in animals, body mass index (BMI), intelligent quotient (IQ), learning ability, blood pressure (BP), etc. QTs can also be categorized into three different ways: (I) morphometric traits cover the analysis of morphology or size and shape of any individual, e.g., BMI; (II) psychometric traits measure the cognitive ability and mental agility of a person, e.g., IQ; and (III) physiometric traits related to the physiological measurements of the body, e.g., BP. In this article, we emphasize three QTs mentioned above. BMI is a mathematical approach used to estimate a person's health status based on height and weight $\left(\mathrm{BMI}=\right.$ weight $(\mathrm{kg}) /\left(\right.$ height $\left.\left(\mathrm{m}^{2}\right)\right)$. BMI helps us to categorize the person's health into four groups, i.e., underweight (BMI below 18.5), normal or healthy weight (18.5-24.9), overweight (25.0-29.9) and obese (30) and above [4]. IQ refers to the efficacy of mental functioning underlying behavior depending on specific criteria. Therefore, it is used to see how effectively someone can utilize reasoning and facts to answer questions and make predictions. The equation used to calculate a person's IQ score is $\frac{\text { mental age }}{\text { chronological age } \times 100}$. Home-Global IQ Institute. Factors influencing IQ are genetics, genotype-environmental (GXE) interaction, gender, family and school environment, society influence (poverty/race/ethnicity), etc. [5]. Another trait is BP, which is expressed as a twodigit figure, i.e., SBP and DBP (systolic and diastolic blood pressure). Hypertension is defined as an increase in BP of greater than $140 / 90 \mathrm{mmHg}$. In contrast, hypotension is defined as a SBP of $90 / 60 \mathrm{mmHg}$ or lower. BP is a complex condition, and various factors, including heredity, physiology, environmental reaction, lifestyle, etc., influence it $[6,7]$. Although these quantitative traits have been extensively studied, various studies have reported phenotypic associations among all three traits; therefore, a common SNP-based study of the association becomes essential [8-15]. To our knowledge, no common SNPs or polymorphisms have been categorized concerning these three quantitative variables, namely BMI, IQ and BP. So, in the present study, we searched and tabulated various SNPs related to these attributes. SNPedia, RefSNP Report, GWAS Catalog, Gene Cards (Databases), PubMed and Google Scholar search engines were used to find relevant information about SNPs related to three QTs, using the keywords "Quantitative traits SNPs", "BMI SNPs", "IQ SNPs", "hypertension/hypotension SNPs", "role of SNPs", "Gene function", and "GWAS" in various combinations. More than 340 articles were retained by using the aforementioned keywords, and about 182 pieces of literature (reviews and original articles) stating significant associations were included. Then, all SNPs were tabulated related to traits in question, and finally common SNPs were uncovered for the same.

\section{SNPs associated with BMI}

Various genome-wide association studies (GWAS) and extensive population-based research have discovered many SNPs linked to BMI/obesity. SNP such as rs653178 (12q24.12) is present in the intron of the gene ATXN2 (Ataxin-2), which codes proteins that are required essentially for endocytosis and mitochondrial functions $\left(p<5 \times 10^{-7}\right)$. GWAS and other knock-out studies have shown that ATXN2 regulates $\mathrm{Ca}^{+2}$ storage and enzymes of mitochondrial matrix and may develop insulin resistance and dyslipidemia after loss of its functions and ultimately leads to high BMI/Obesity [13-16]. Another SNP rs12411886 is also present in the intronic region of gene CNNM2 on chromosome 10; a GWAS has reported its association $\left(p<4 \times 10^{-5}\right)$ with BMI and cardiovascular risk disease (CVD). However, CNNM2 called cyclin M2 encodes for transmembrane protein involved in the transport of $\mathrm{Mg}^{+2}$ ions and is highly expressed during brain and kidney development. rs794356 is present in the intron of HIP1 (7q11.23) gene. HIP1 (huntingtininteracting protein-1) encodes for a protein, i.e., one of the members of clathrin mediated endocytosis and trafficking; therefore, HIP1 is necessary for fundamental cellular and organismal homeostasis in vivo phenotypes and deficiency of HIP1 may lead to adult weight loss and early death [17]. rs1167266 is another SNP associated with BMI located in the intronic sequence of GIPR gene on chromosome $19\left(p<1.64 \times 10^{-4}\right)$. This gene encodes a G-protein coupled receptor for gastric inhibitory polypeptide (GIP), which was first discovered in gut extracts to block stomach acid production and gastrin release but was later shown to promote insulin release in context of high glucose. According to knock-out research on GIPR $^{-1-}$ mice, an oral glucose dosage raises blood glucose levels with compromised early insulin response; as a result, a mutation in this gene may have a role in development of diabetes [18]. Another trans-ethnic 
analysis of metabochip data has identified two SNPs rs2820436 $\left(p<3.79 \times 10^{-8}\right)$, LYPLAL1 on chromosome 1 and rs10930502 $\left(p<2.5 \times 10^{-7}\right)$ METAP1D on chromosome 2 associated with BMI. The LYPLAL1 (Lysophospholipase Like 1) gene codes for a protein that plays a role in hydrolase activity and lysophospholipase activity, while METAP1D (Methionyl Aminopeptidase Type 1D) is a mitochondrial protein coding gene that is associated with aminopeptidase activity and metalloaminopeptidase activity; thus, these activities might have possible impact on pathways that regulate metabolism and adipose tissue [19]. Some other SNPs like rs1934100 $\left(p<5 \times 10^{-8}\right)$ in ELAVL2 gene on chromosome 9 and rs1720825 in MRAS gene on chromosome 3 are also intron variants, while rs754635 $\left(p<5 \times 10^{-8}\right)$ in CCK gene on chromosome 3 is splice region variant, and rs7176527 in ZSCAN2 on chromosome 15 is intergenic variant. All these SNPs are linked to an increase in BMI [17, 19-21], while rs1720825, rs7176527, rs1167266, rs794356 and rs653178 are linked to additional traits, e.g., CVD, waist circumference (WC), type II diabetes (T2D), glucose homeostasis, insomnia and DBP, respectively [17]. There is a list of SNPs associated with BMI (Table 1).

\section{SNPs associated with IQ}

Since intelligence is associated with important economic and health-related life outcomes, a genome-wide association meta-analysis of 78,308 individuals identifies 336 SNPs associated with intelligence, implying that genes are important in regulating the maturation of neurons and others linked to intellectual disability and cerebral malformation [67]. Apart from rs12411886 in CNNM2 (mentioned above), there are various other SNPs like rs66495454 in NEGR1, $\left(p<9.08 \times 10^{-9}\right)$, rs236330 in FNBP1L and rs12744310 $\left(p<4.2 \times 10^{-9}\right)$ chromosome 1 ; rs3846329 in NR3C2 at chromosome 4; rs2490272 in FOXO3 and rs1011313 in DTNBP1 gene at chromosome 6; rs10236197 in PDE1C $\left(p<1.03 \times 10^{-10}\right)$ at chromosome 7; rs411280 in NTM at chromosome 11; rs2251499 intergenic at chromosome13; rs16954078 in $\operatorname{SKAP} 1\left(p<2.84 \times 10^{-8}\right)$ at chromosome 17 ; and rs113315451 in CSE1L $\left(p<1.15 \times 10^{-8}\right)$ at chromosome 20 are linked to IQ [68-71]. NEGR1 codes for neuronal growth regulators and is associated with Niemann-Pick disease and leptin deficiency/dysfunction. It is involved in cell adhesion and functions as a trans-neural growthpromoting factor in regenerative axon sprouting in the mammalian brain (genecard.org). While another gene on chromosome 1 encoding a protein that promotes CDC42-induced actin polymerization by activating the N-WASP-WIP complex, FNBP1L produces a protein that promotes CDC42-induced actin polymerization by activating the N-WASP-WIP complex. Actin polymerization may increase membrane tubule fission and the formation of endocytic vesicles. rs2490272 is an intronic FOXO3 (Forkhead Box O3) SNP that was found to be associated $\left(p<9.96 \times 10^{-14}\right)$ with intelligence. FOXO3 is a gene that codes for proteins which activate PI3K/AKT and cause apoptosis in the absence of survival factors, including neuronal cell death in response to oxidative stress. Details of additional IQ-related SNPs (Table 2).

\section{SNPs associated with BP (hypertension / hypotension)}

A number of SNPs were identified with a varied impact on BP. Some SNPs that are identified in strong association with BP. A GWAS of blood pressure based on 200,000 European peoples has identified 16 new loci it. Out of these loci, the rs11953630 $\left(p=1 \times 10^{-4}\right)$ is found in EBF1 gene at chromosome 5, coding for EBF transcription factor 1, a DNA binding homodimer that forms complexes with the Mb1 promoter, and strongly activates the transcription. Some studies have found high levels of Ebf expression in lymph node, spleen, and adipose tissues and low levels in several nonlymphoid tissues [65, 97], Another BP-associated variant rs7129220 $\left(p=4 \times 10^{-7}\right)$ is an intronic variant present in AMPD3 at chromosomes $11(11 \mathrm{p} 15.4)$. This gene is responsible for coding Adenosine Monophosphate Deaminase 3, an enzyme involved in adenylate catabolic pathway, in which it converts adenosine monophosphate to inosine monophosphate, by hydrolytic deamination process; therefore, it has critical role in energy metabolism and vascular blood flow to direct nutrient and oxygen delivery (www.omim.org; www.genecards.org; [65]. The rs805303 is considerably associated with hypertension $\left(p=1 \times 10^{-10}\right)$ and found in BAG6 at chromosome $6[65,98]$. The BAG6/BAT3 complex functions as a chaperone, preventing soluble proteins from aggregating and assisting in their transport to the endoplasmic reticulum or, alternatively, promoting their sorting to the proteasome, where they are degraded. As a result, the BAG6 protein is engaged in a variety of cellular activities, including apoptosis, gene regulation, protein synthesis, quality management and protein degradation. It is yet unclear if the variation rs 805303 affects BAG6's regulatory or functional capabilities. According to expression analyses, the 'AA' genotype of rs805303 reduces BAG6 expression in the coronary and tibial arteries, the aorta, the sigmoid colon and the esophagus www.genecards.org [99]. The $\operatorname{rs} 2286672\left(p=3 \times 10^{-9}\right)$ in PLD2 locus at chromosome 17 is a missense variant (R172C) and found associated with hypertension. Although PLD2 gene encodes for phospholipase 2 protein and essentially acts in the hydrolysis of phosphatidylcholine to phosphatidic acid and choline, PLD2 is also involved in cytoskeletal organization, cell cycle control, 


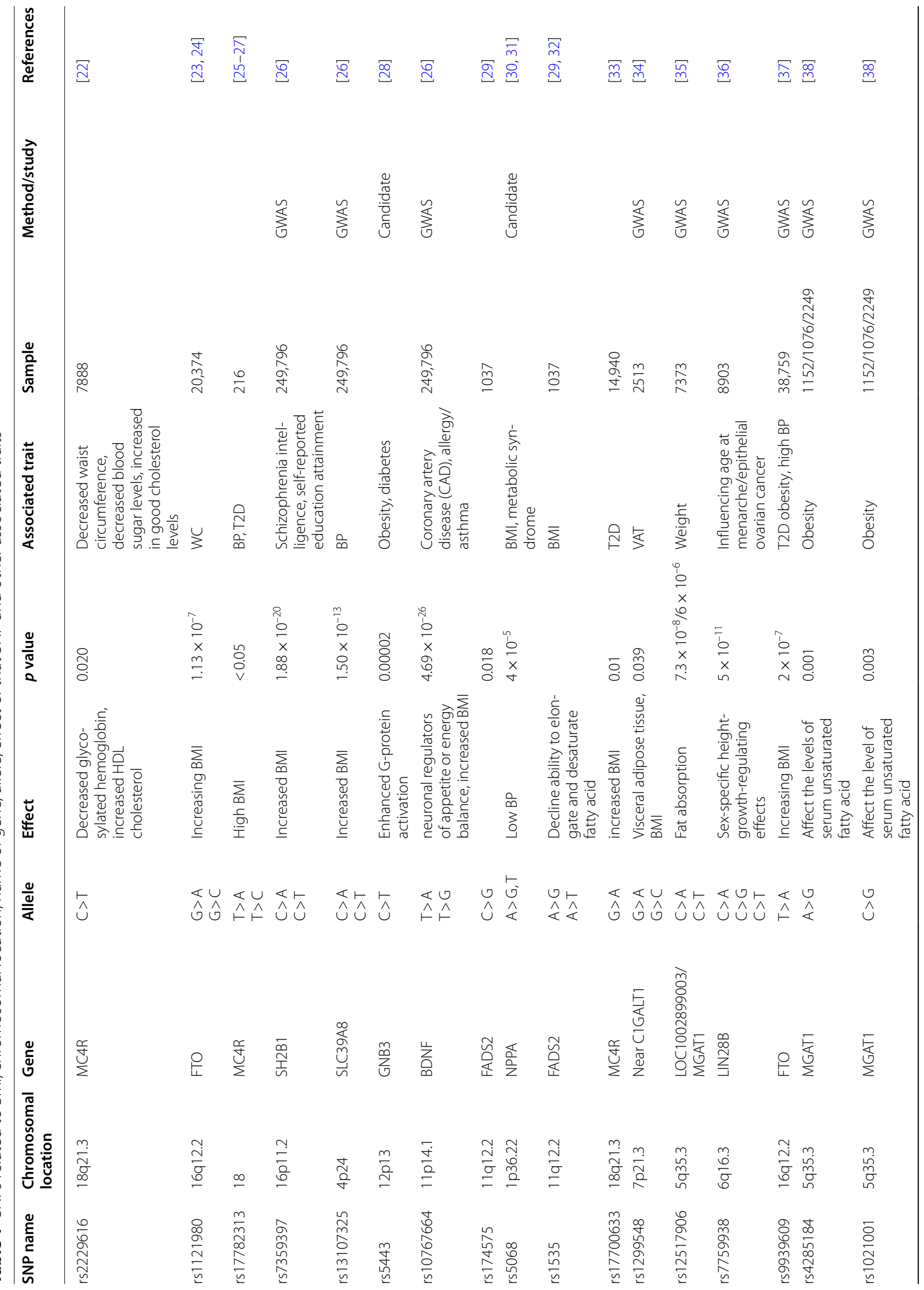




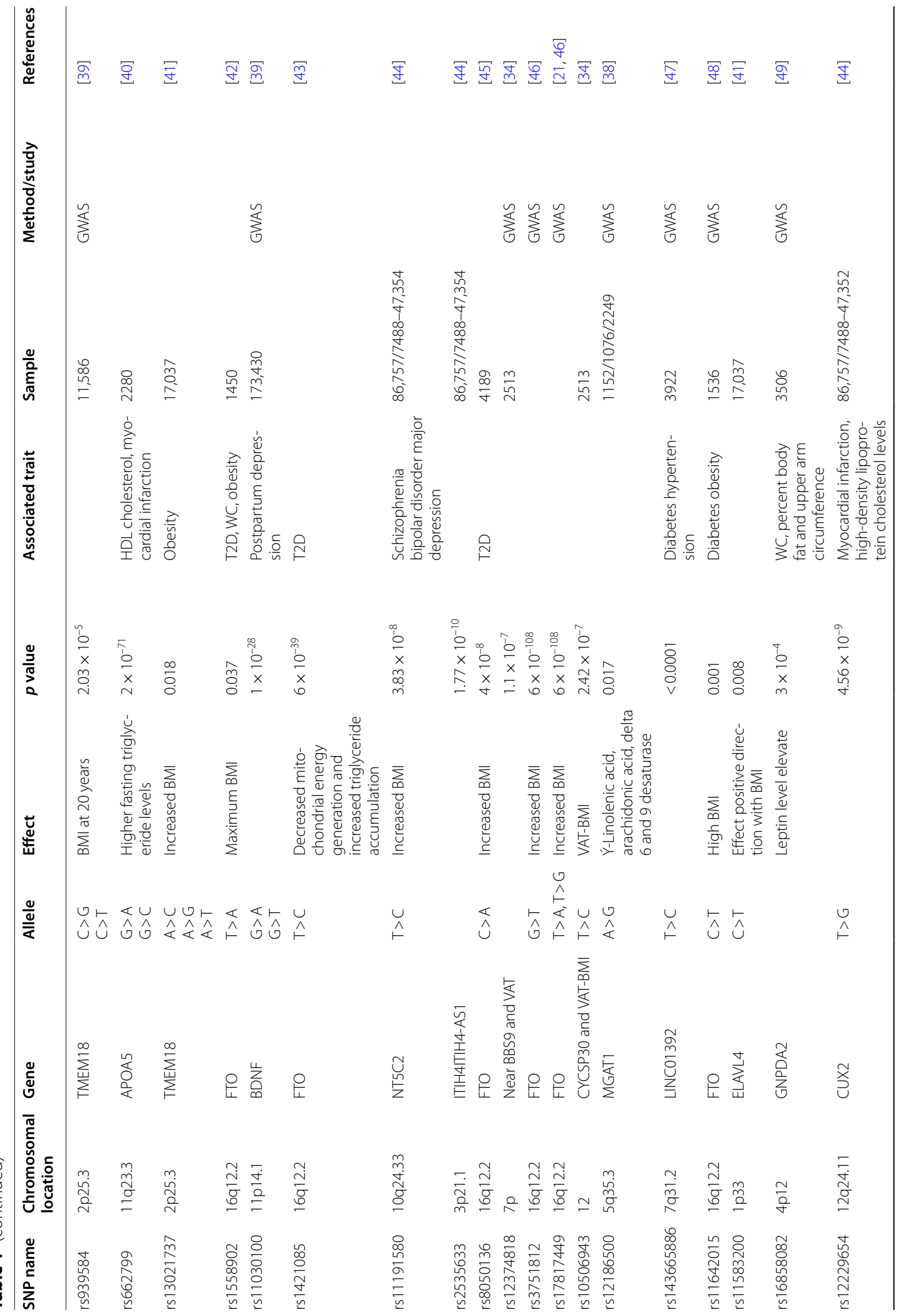




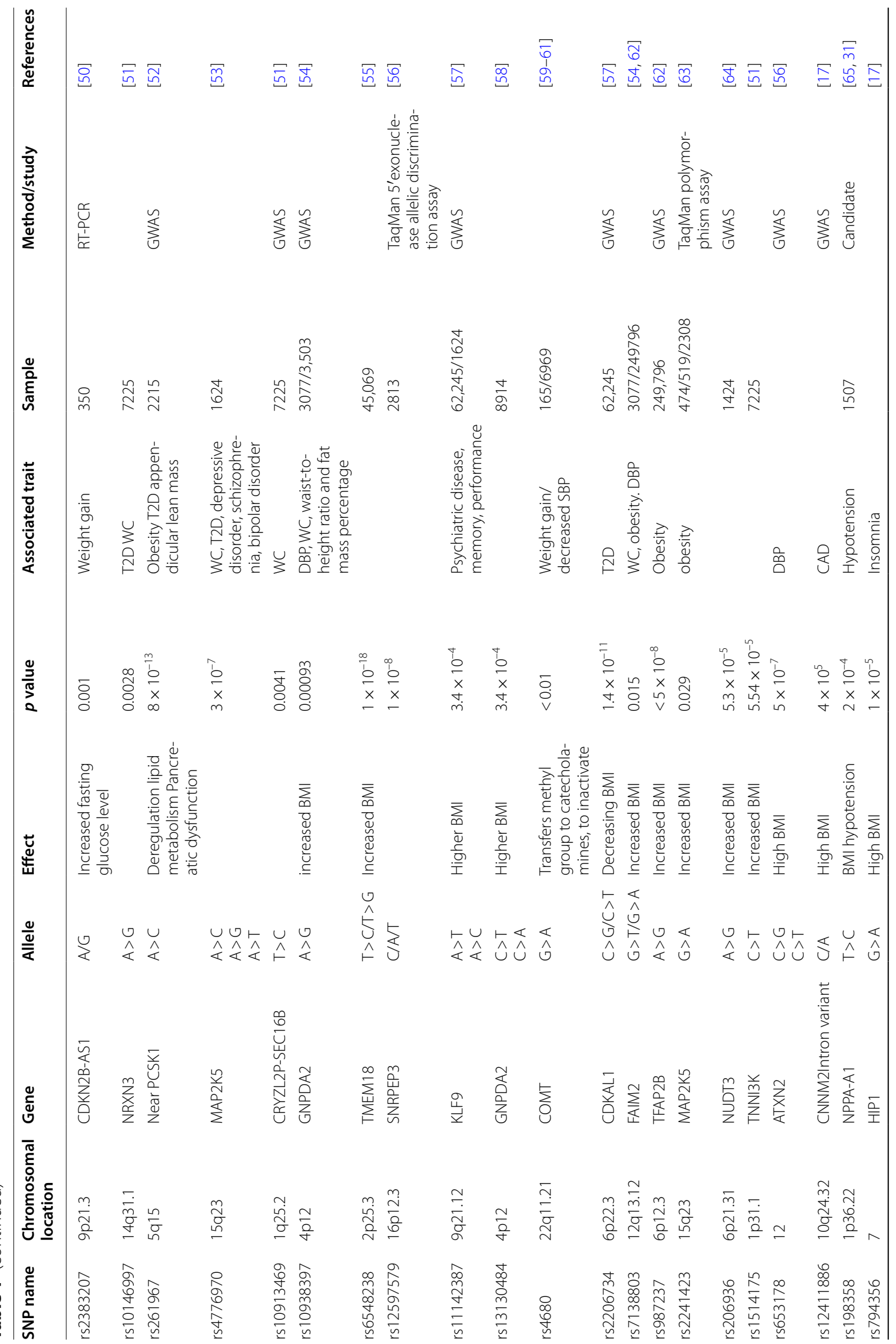




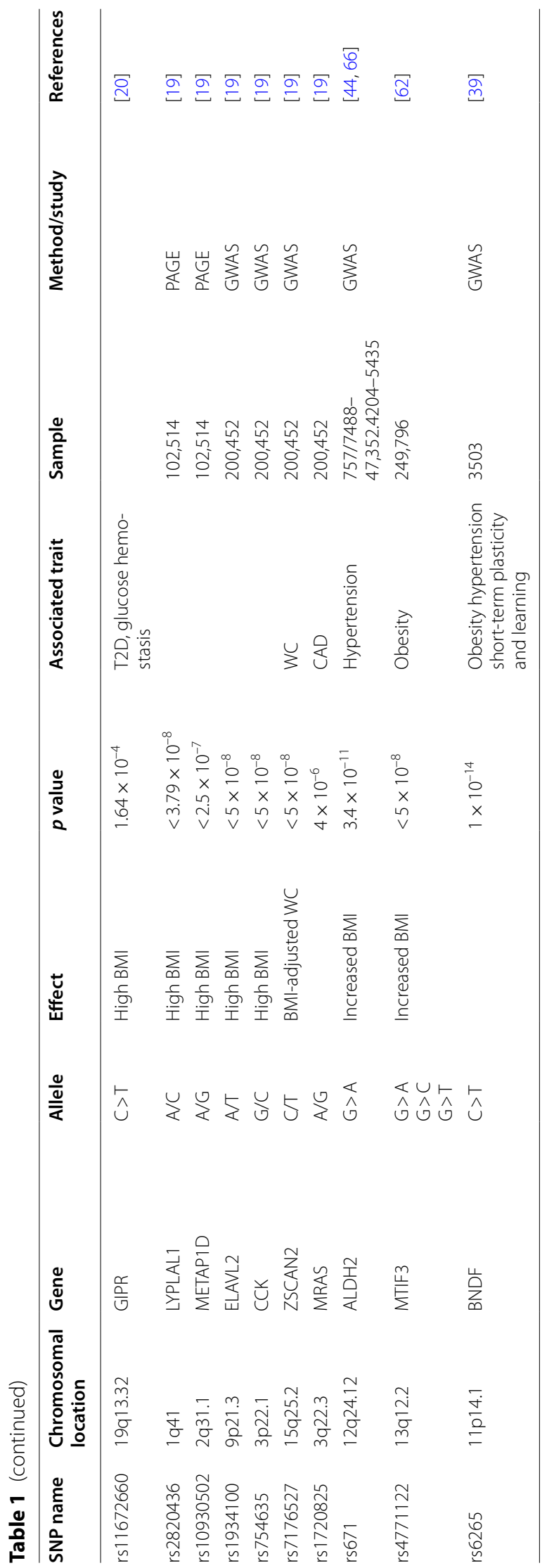




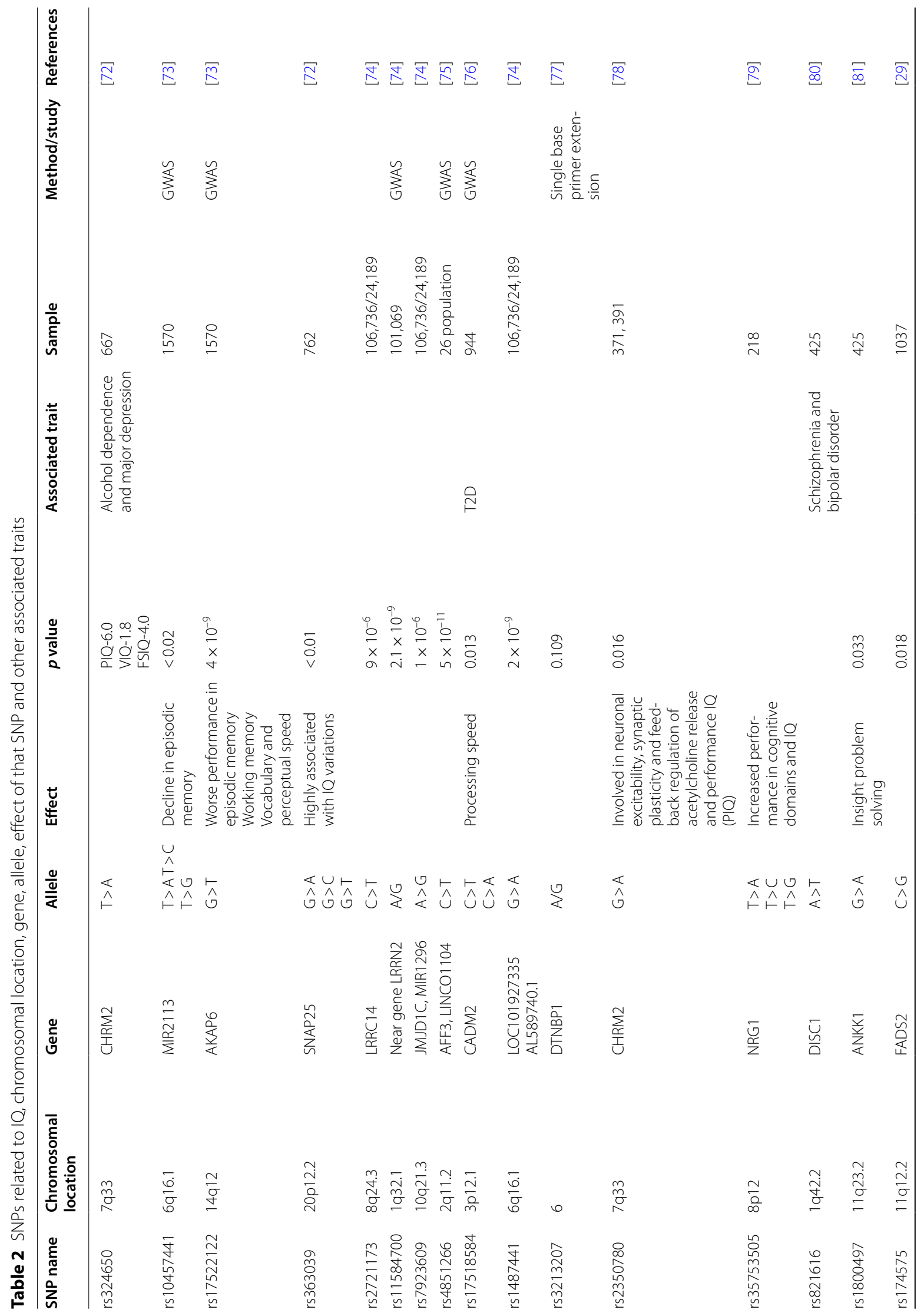




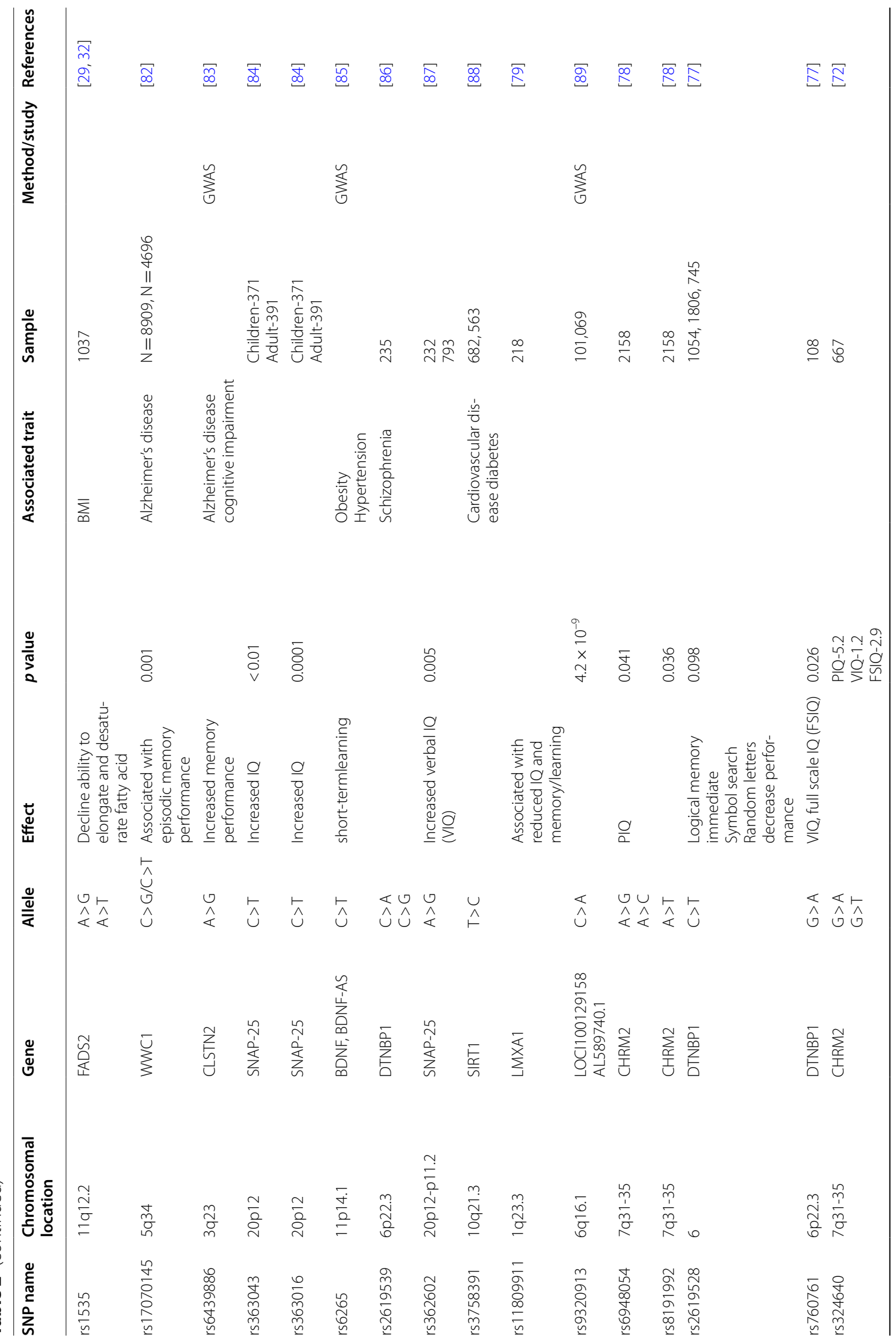




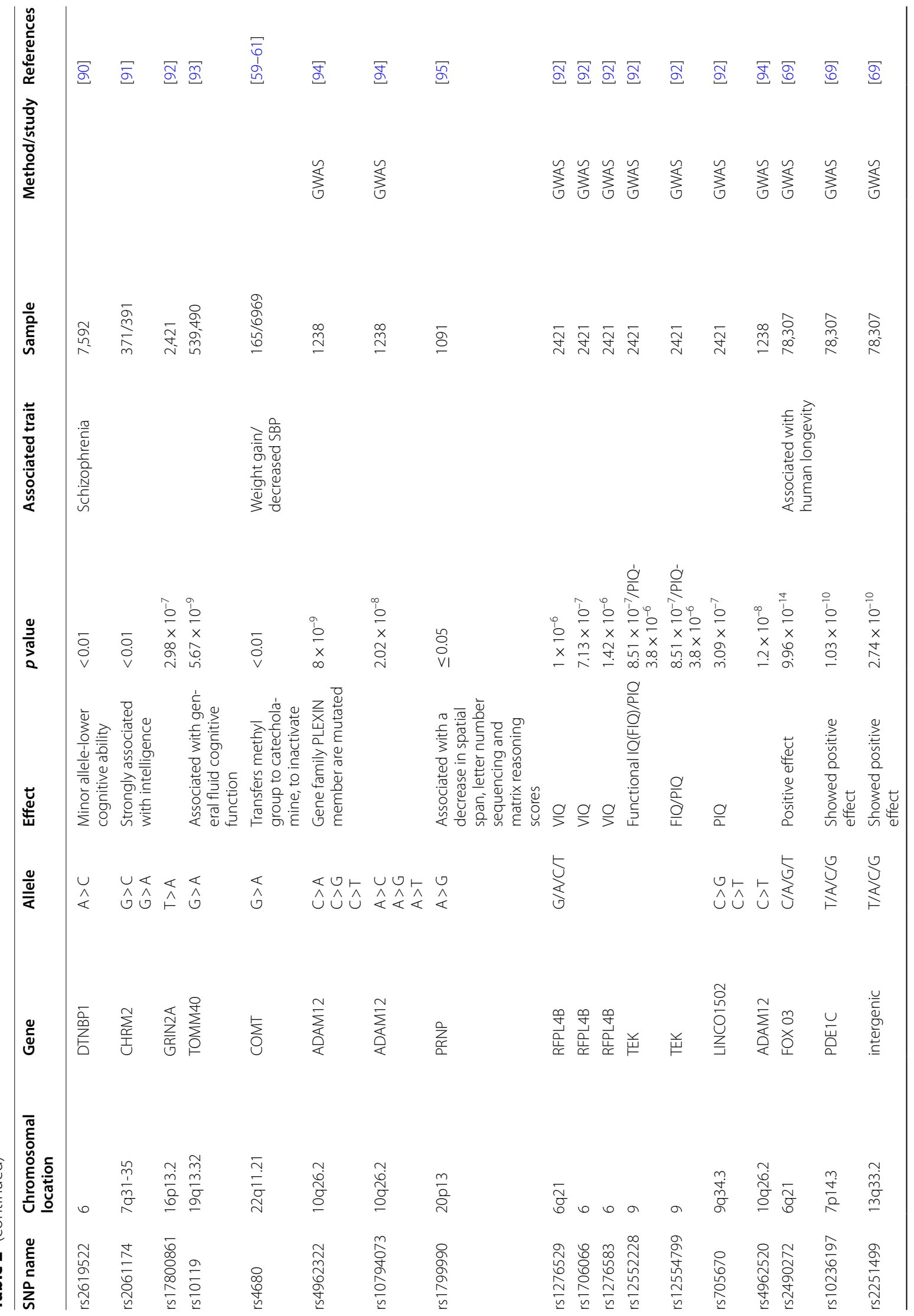




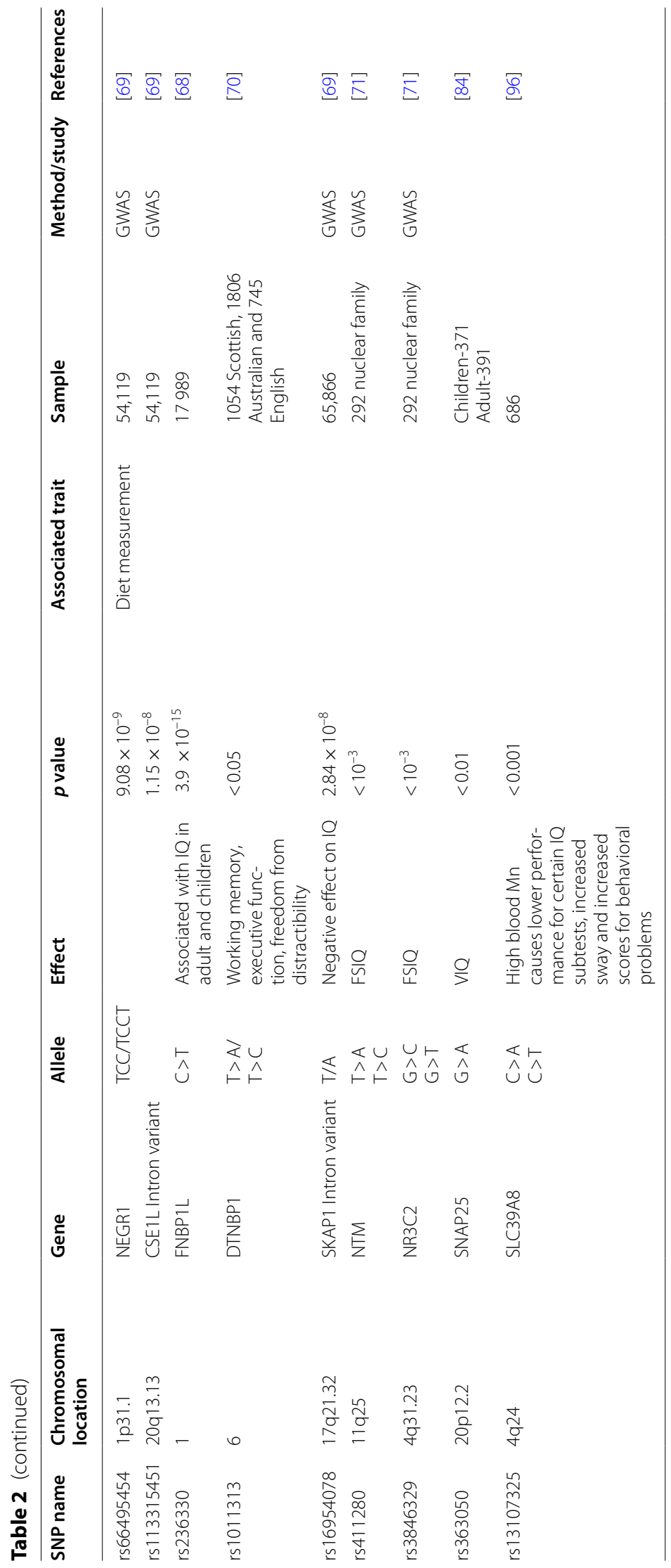


transcriptional regulation and/or regulated secretion. Another missense variant, rs16835244 $\left(p=1 \times 10^{-3}\right)$, is found on chromosome 1 in AZIN2 and substitutes Ala288 in the arginine decarboxylase (ADC) with serine [98]. Antizyme inhibitor (AZIN) family member arginine decarboxylase (ADC) assist in cell growth and proliferation by ensuring polyamine homeostasis inside the cell [100]. rs4963 and rs17833172 in ADD1 at chromosome 4 have been strongly associated to the BP. A study looked at the relationship between the rs17833172 variation and systolic, diastolic and mean arterial pressure in responses to a high-sodium intervention, as well as DBP responses to a low-sodium intervention. Two copies of the ' $\mathrm{A}$ ' allele of rs17833172 reduce the response to salt consumption substantially [101]. Similarly, another study found rs4963, which is Gly460Trp polymorphism of ADD1 gene, to be involved $(p=0.0003)$ in the increased salt sensitivity of BP and hypertension [101-103]. The gene NEDD4L, which controls the amiloride-sensitive epithelial sodium channel, is also a potential gene for salt sensitivity (ENaC). In NEDD4L at chromosome 18, rs2288774 (C/T) polymorphism and rs4149601 (G/A), GG genotype is essential for encoding the protein's $\mathrm{C} 2$ domain. These NEDD4L genotypes were shown to be therapeutically beneficial ( $p=0.007$ and $p=0.07)$ in identifying patients, who benefit from dietary salt restriction in management of hypertension [102, 103]. A study during the Japanese National Project shows two SNPs rs3794260 (G/A) $(p=0.0001)$ and rs9739493 (T/C) in KIAA0789 at chromosome 12, exhibited the susceptibility of KIAA0789 gene for hypertension [104]. Another study analyzed 14 million variants among 815 adolescents for genetic association studies of BP showed the association of rs181430167 $\left(p=6.8 \times 10^{-7}\right)$ with SBP and rs12991132 $\left(p=4.0 \times 10^{-7}\right)$ with DBP [105]. For additional SNPs concerning BP, see Table 3. After tabulating all the collected data of SNPs, we arranged these different SNPs according to their involvement in the determination of any two or three traits.

\section{Common SNPs associated with BMI and BP/ hyper-hypotension}

We discovered some SNPs that are actively participating in determination of BMI and BP [132]. Scientists examined through study of $\sim 15,000$ Europeans that the rs5068 in NPPA gene is ( $3^{\prime} \mathrm{UTR}$ region variant) at $1 \mathrm{p} 36.22$ chromosome, is strongly associated $\left(p=8 \times 10^{-70}\right)$ with increased circulating natriuretic peptide and thus lower BP. The gene CDKN2B-AS1 produces a functional RNA molecule that interacts with polycomb repressive complexes 1 and 2, resulting in epigenetic silencing of other genes in the cluster. This region is also linked to a variety of different diseases, including numerous malignancies, intracranial aneurysms, T2D, periodontitis, Alzheimer's disease, endometriosis, weakness in the elderly and glaucoma. The SNP rs2383207 in CDKN2B-AS1(Intron variant) found at chromosome $9(9 \mathrm{p} 21.3)$ was proposed to be linked with elevated risk for coronary artery disease in a Korean population $(p=0.001)$ [139], ischemic stroke risk in Sweden people $(p=0.04)$ [140] and G allele of SNP rs2383207 with the internal carotid artery and intima-media thickness $(p=0.007)$ [141] therefore, such genetic variation at the CDKN2A/CDKN2B locus can be used as a marker to predict stroke in hypertensive patients [131]. Some other reports have found that obesity, BMI, coronary artery disease (CAD), insulin resistance and therefore diabetes, left ventricular hypertrophy and hypertension have all been related to rs 5443 in the G-protein beta3 subunit (GNB3) gene at 12p13 chromosome, which is more generally known as the C825T variation [28, 142]. Another gene, named FTO (FTO Alpha-Ketoglutarate Dependent Dioxygenase) also known as "Fat gene", has rs9939609, an intron variant at 16q12.2 chromosome, which is related to SBP [54] elevated BMI along with rs17782313 on MCAR (Intergenic variant) at $18 \mathrm{q} 21.3$ [143] and negatively associated with DBP and mean BP with hypertension [25]. The rs10938397 on GNPDA2 (Intergenic variant) at 4p12 chromosome was associated with DBP $(p=0.026)$ [54] and with BMI [144] The SNP rs671, a missense variant and a classical one known for the phenomenon "Asian flush" or "Asian blush" or "Alcohol flush" in gene ALDH2 (aldehyde dehydrogenase) at 12q24.12 chromosome, causes red face in some individuals after drinking alcohol. This SNP has been published in association with essential hypertension (based on drinking behavior) and BMI/ Obesity $[145,146]$ but the study [147] denies the association of rs671 with essential hypertension. The rs653178 (explained above) in gene ATXN2 has also been reported in relation $(p=0.006)$ with essential hypertension [148] (Table 4).

\section{Common SNPs associated with BMI and IQ}

High BMI is considered as a marker of obesity and therefore has association with increased health burden such as Type II Diabetes (T2D) and CVD [149-151]. It is also linked to a decline in cognitive performance, with brain atrophy and T2D being two probable causes $[152,153]$. The SNPs rs1535 and rs174575 in FADS2-fatty acid desaturase 2 enzyme have been implicated in moderating the effects of breastfeeding on IQ in several studies with a marginal $p$-value $[29,154,155]$. The FADS2 is a fatty acyl-coenzyme A (CoA) desaturase that introduces a cis double bond at carbon 6 of the fatty acyl chain during the biosynthesis of highly unsaturated fatty acids (HUFA) from the essential polyunsaturated fatty acids (PUFA), 


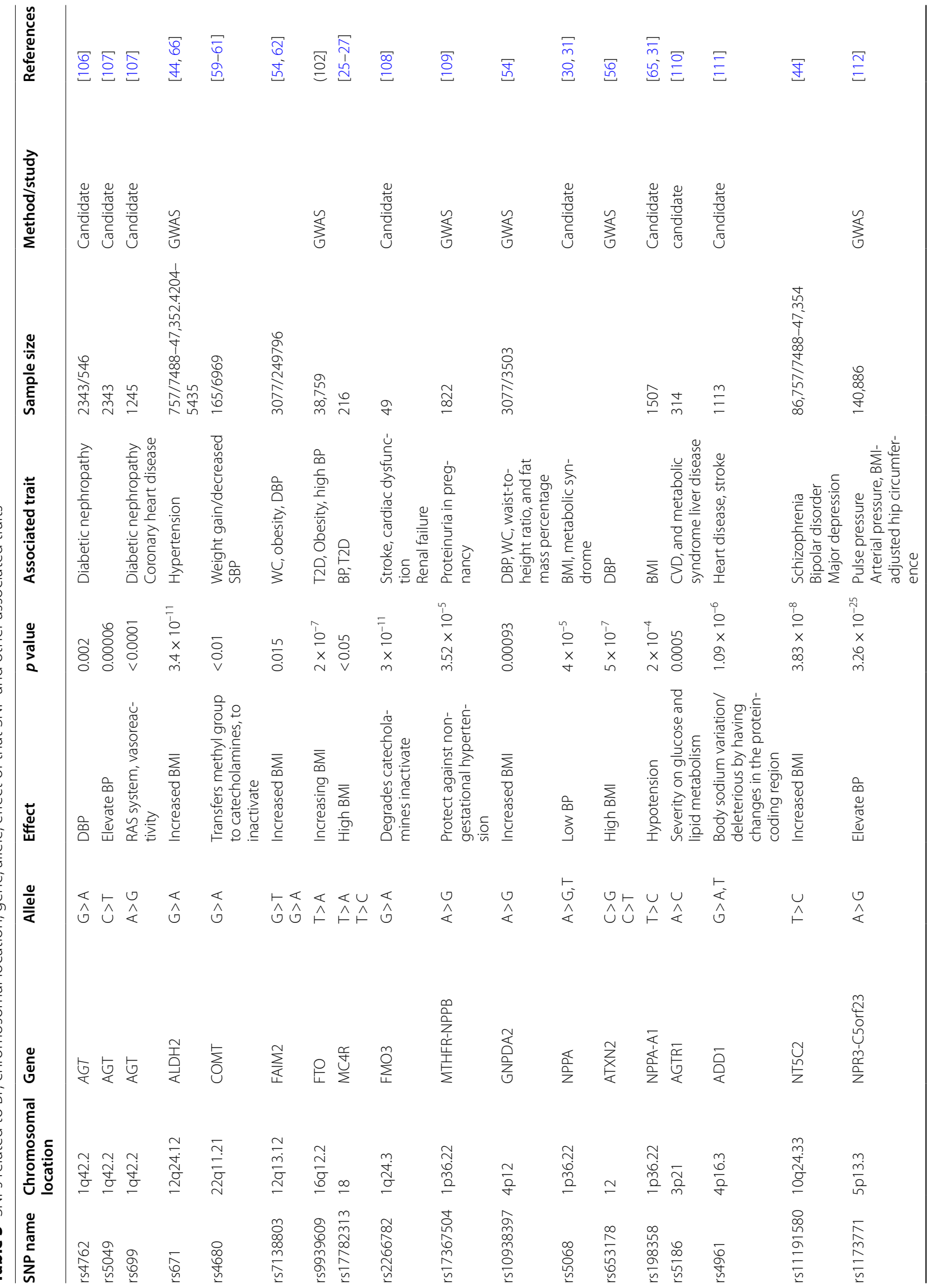




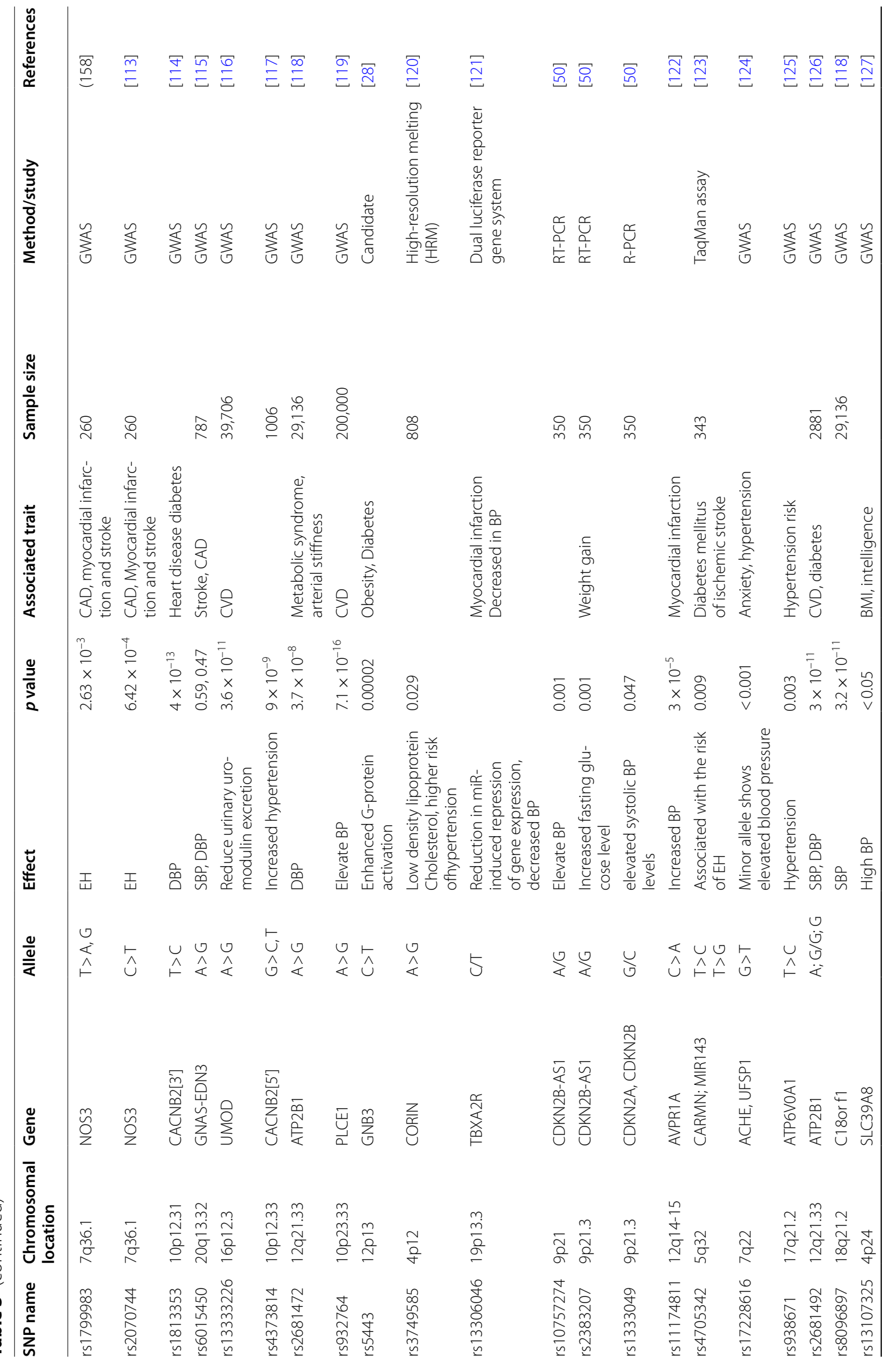




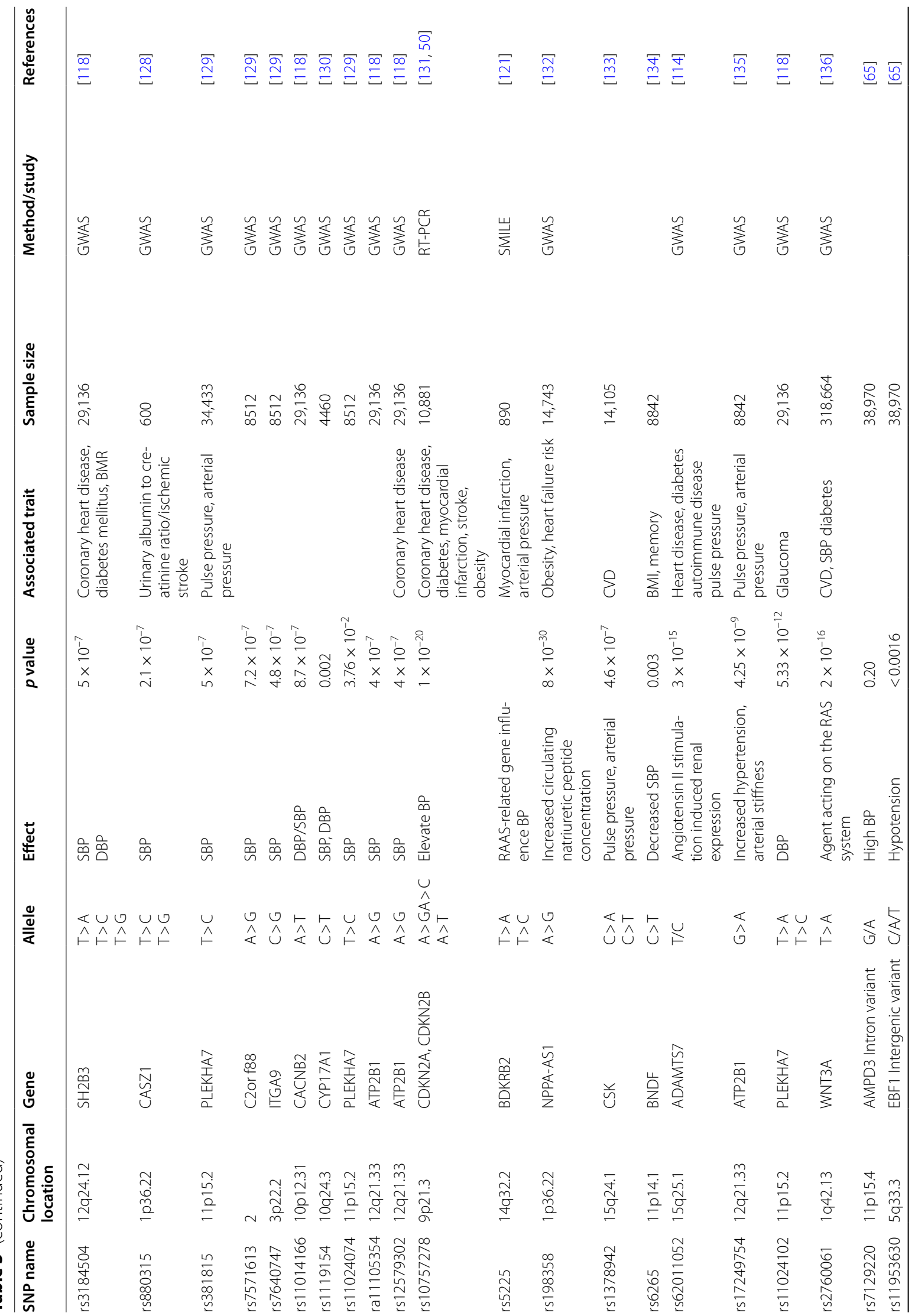




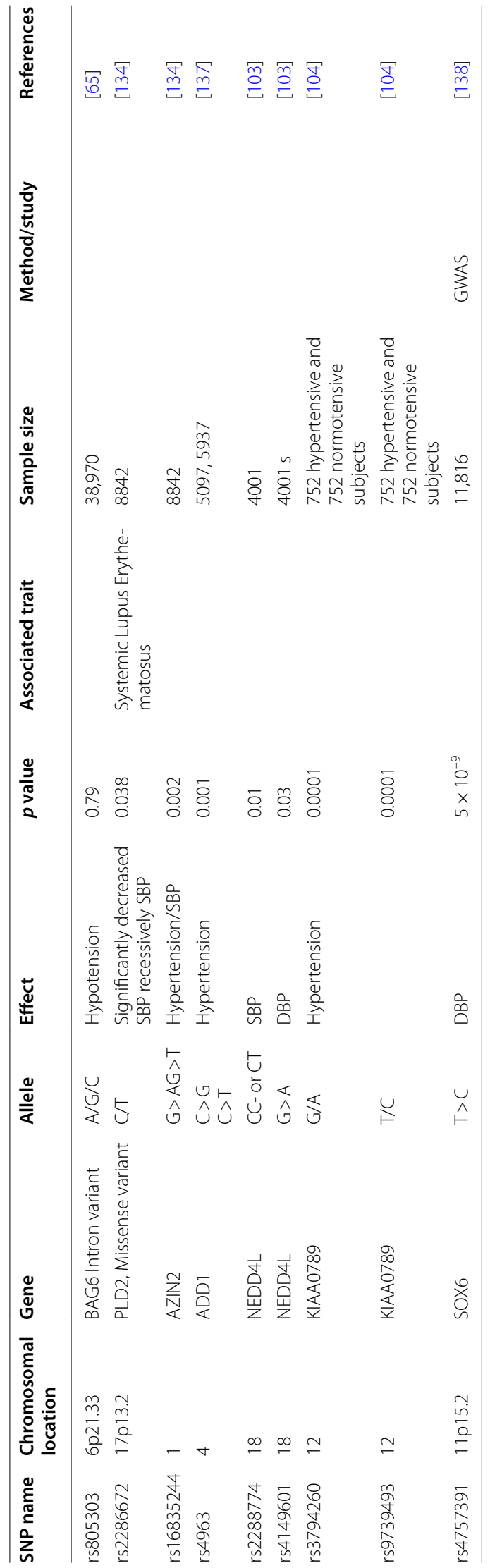


Table 4 Common SNPs for QTs selected in the present study in different combinations

\begin{tabular}{|c|c|c|c|}
\hline SNPs & Chromosome & Gene & Gene variant \\
\hline \multicolumn{4}{|c|}{ Common SNPs related to BMI and IQ } \\
\hline rs1535 & $11 q 12.2$ & FADS2 & Intron variant \\
\hline rs174575 & $11 q 12.2$ & FADS2 & Intron variant \\
\hline \multicolumn{4}{|c|}{ Common SNPs related to $I Q$ and $B P$} \\
\hline No SNPs & - & - & - \\
\hline \multicolumn{4}{|c|}{ Common SNPs related to $B M I$ and $B P$} \\
\hline rs5068 & $1 p 36.22$ & NPPA & $3^{\prime}$ utr region \\
\hline rs2383207 & $9 p 21.3$ & CDKN2B-AS1 & Intron variant \\
\hline rs5443 & $12 \mathrm{p} 13$ & GNB3 & Synonymous variant \\
\hline rs9939609 & $16 q 12.2$ & FTO & Intron variant \\
\hline rs17782313 & $18 q 21.3$ & MCAR & Intergenic variant \\
\hline rs10938397 & $4 p 12$ & GNPDA2 & Intergenic variant \\
\hline rs671 & $12 q 24.12$ & $\mathrm{ALDH} 2$ & Missense variant \\
\hline rs7138803 & $12 q 13.2$ & FAIM2 & Intergenic variant \\
\hline rs198358 & 1p36.22 & NPPA & $3^{\prime}$ utr region \\
\hline rs653178 & $12 \mathrm{q} 24.12$ & ATXN2 & Intron variant \\
\hline rs11191580 & $10 q 24.33$ & NT5C2 & Intron variant \\
\hline \multicolumn{4}{|c|}{$\begin{array}{l}\text { Common SNPs identified for all three QTS, viz. BMI, IQ and } \\
B P\end{array}$} \\
\hline rs6265 & 11 p14.1 & BDNF & Missense variant \\
\hline rs4680 & $22 q 11.21$ & COMT & Missense variant \\
\hline rs13107325 & $4 p 24$ & SLC39A8 & Missense variant \\
\hline
\end{tabular}

linoleic acid and alpha-linolenic acid precursors [156]. Breastfeeding indicates to be connected with higher IQ in observational studies and randomized controlled trials, presumably because breast milk contains long-chain PUFA [155]. The well-studied SNP rs4680 (Missense variant $=$ Val158Met $)$ in COMT-Catechol-O-methyltransferase gene occurs at 22q11.21 chromosome. The COMT gene produces the COMT enzyme, which degrades dopamine in the prefrontal cortex of the brain. The wildtype allele is a $(G)$, which codes for valine; the (A) alteration polymorphism switches valine to methionine. The configuration of the resulting enzyme is changed, and its functionality is reduced to $25 \%$ of that of wild type [157]. Multiple studies indicates the involvement of this SNP in decrease in IQ as maternal anxiety increase [59], and in neurological disorders i.e., bipolar disorder [158] schizophrenia [159, 160] Alzheimer's disease [161] and psychiatric disorders [162]. This variant is also known to be involved in increment of BMI $(p=0.002)$ [163]. In another empirical study, 1,000 random drawings of 812 and 6649 SNPs from the 2,475,536 variations yielded an overlap of 7 or more SNPs on seven occasions, showing a substantial enrichment for hits $(p=0.007)$. The seven SNPs found were in four genes: AKAP6 (rs17522122), TOMM40 (rs2075650), TMEM161B (rs2410767, rs6870983, rs7445169) and TNRC6B (rs2410767, rs6870983, rs7445169) (rs4820408, rs8142495). With the exception of the TOMM40 variant (rs429358), the impact sizes for SNPs in concern were in reverse direction (variants that are significantly linked with general cognitive function are inversely associated with BMI) [164]. Furthermore, a recent study found a link between a higher BMI and a decreased risk of dementia. Both cognitive performance and BMI have been shown to be influenced by genetic factors in studies [93, 165-167] (Table 4).

\section{Common SNPs associated with BP and IQ}

Hypertension and/or increments in BP (systolic, diastolic or mean atrial pressure (MAP)) were statistically significant predictors of progressive decline in Cognitive performance (linear and nonlinear) over time. The hypertension and BP-associated decline in cognitive performance reported in these studies were seen with control for stroke, dementia, CVD risk factors, comorbidity and antihypertensive treatment [168]. The consequences of pediatric hypertension on the nervous system have been detailed in a study, with acute neurological involvement ranging from posterior reversible encephalopathy syndrome to infarction and hemorrhage. Learning difficulties and executive function deficits are common in children with chronic hypertension, which may be treatable with antihypertensive therapy [169]. A population-based 
(a)

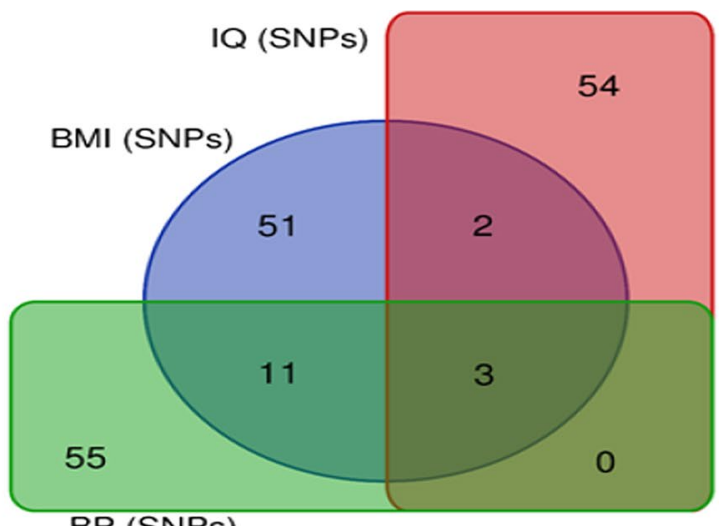

BP (SNPs)

(b)

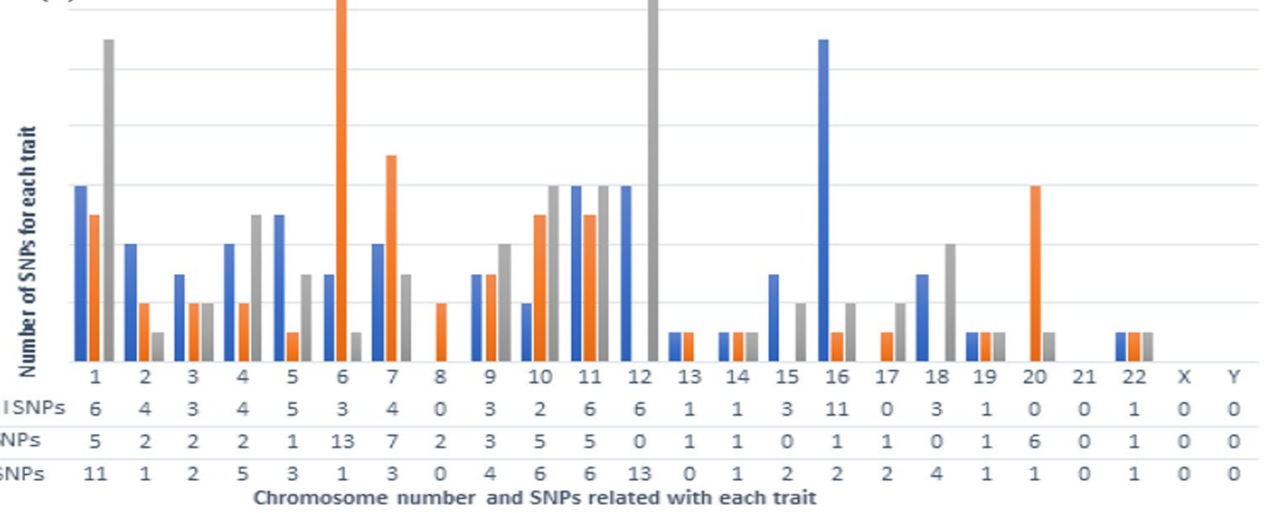

Fig. 1 a Venn diagram showing the number of SNPs associated with BMI, IQ and BP (individually and in combinations). It is evident from picture that 51, 54 and 55 SNPs associated only with BMI, IQ and BP respectively, 11 common SNPs for BP and BMI, 2 common SNPs for IQ and BMI and no common SNP for BP and IQ. Only 3 SNPs are common for all three traits. $\mathbf{b}$ Bar graph showing the number of SNPs for each trait and their location on chromosomes

GWAS found a probable association between hypotension and cognitive impairment in healthy elderly adults. With the exception of rs117129097, which was connected to hypotension, LRRTM4 (rs13388459, rs1075716, rs62171995, rs17406146, rs2077823 and rs62170897), PCSK5 (rs 10521467) and the intergenic SNP rs117129097 were shown to be markers for cognitive impairment (CI), coexisting with hypotension in the current study. Inadequate cerebral perfusion, loss of autoregulation, and endothelial dysfunction in the neurovascular unit are suggested to be the processes of hypotension-related CI, which leads to microvascular pathology, stroke, and the accumulation of $A \beta$ protein and neurofibrillary tangles. The removal of $A \beta$ from the brain is affected by vascular reactivity, which is altered by microvascular illness [170172] (Table 4).

\section{Common SNPs associated with BMI, IQ and BP}

We discovered three different SNPs involving in these three QTs (BMI, IQ and BP). First, the rs6265 in the BDNF gene, second the rs13107325 in the SL39A8 gene, and third is rs4680 in the COMT gene. The neurotrophin brain-derived neurotrophic factor (BDNF) is abundantly present and highly expressed in brain. This growth factor influences a variety of brain processes related to plasticity and repair [173]. The BDNF polymorphism has been associated to motor learning, short-term plasticity, and the operation of the human brain's motor system. Val66Me is another name for this variant, in which the $\mathrm{G}$ allele codes for $\mathrm{Val}$ and the A allele codes for Met. The people not having this polymorphism, (Val/Val condition) have larger baseline activation volumes (including 


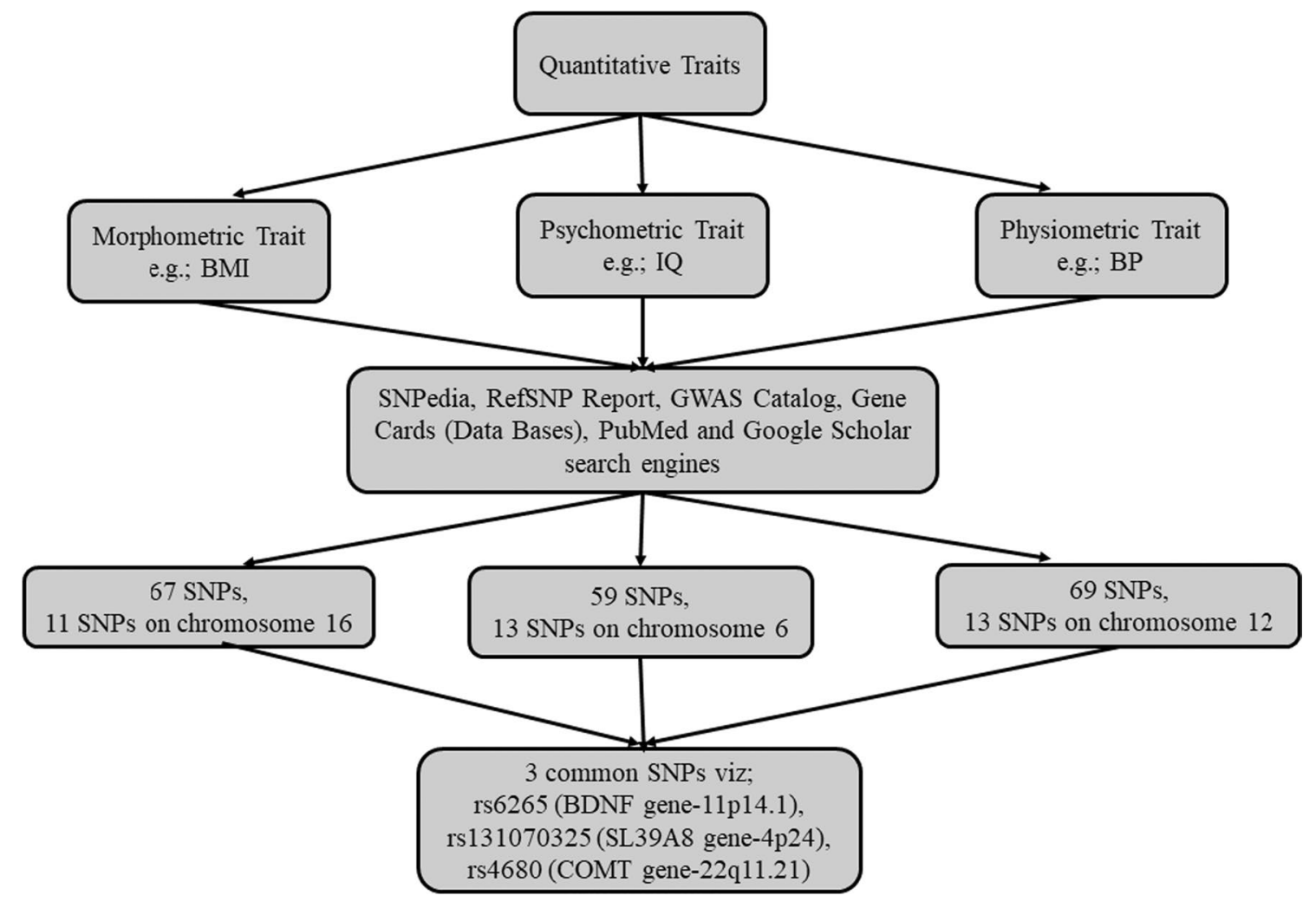

Fig. 2 Flowchart depicting the summary of the present study

inside bilateral sensorimotor cortex) than those having Met condition [85] BP has also been studied in correlation with this SNP rs6265, with a significant reduction in SBP [129]. Another study on this SNP also found a strong association of this SNP to current BMI and change in BMI. The Current BMI is defined as the BMI calculated using self-reported current weight and height, as well as BMI change (per year) calculated using (current BMIBMI at 20)/(age-20) [39]. Another SNP, the SLC39A839 gene is a member of the SLC39 family of solute carrier genes. This gene is located on chromosome 4p24, and rs13107325, a missense variant, has been associated to high BP and BMI $[26,127]$. Poorer scores were connected to the rs13107325 minor allele ( $\mathrm{T}$; lower blood Mn). As a result, genotypes linked to greater blood Mn performed worse on specific IQ subtests, had more sway, and were rated as having more behavioral issues. Mn levels in the blood have been connected to cognitive, behavioral, motor, and sway outcomes in children [96] (Fig. 1a, b; Table 4).

\section{Conclusion}

The majority of biological processes important to human health and medicine, such as height, weight, obesity, IQ and diabetes, are quantitative or complex features. Quantitative qualities are regulated by a large number of genes, each of which has a minor effect and is easily changed by environmental circumstances. The genes that affect a QTs have a large impact, whereas others have a minor impact. The purpose of this study was to use review/research articles all around the world to uncover common SNPs or genes for three quantitative variables in human population (BMI, IQ, BP or hypertension). As a result, we gathered more than 58 significantly linked SNPs for each attribute separately and looked for common SNPs among them. Following that, we discovered 11 common SNPs for BMI/BP, 2 for BMI/IQ and no common SNPs BP/IQ, because the SNPs which were common in $\mathrm{BP} / \mathrm{IQ}$ were also common for all three traits. 
Consequently, we discovered 3 common SNPs in populations for all three QTs, viz. SNP rs6265 at the BDNF gene on chromosome 11p14.1 and SNP rs131070325 at the SL39A8 gene on chromosome 4p24, and SNP rs4680 at the COMT gene on chromosome 22q11.21. By arranging the SNPs according to their location on chromosome we found that most of the SNPs (11) for BMI are present on chromosome 16, 13 SNPs of IQ on chromosome 6 and 13 SNPs for BP on chromosome 12 (Fig. 2).

In our review, we focused on the common SNPs and gene expression activities that influence these three quantitative traits. If these SNPs are found in any population, we can get prior knowledge about the trait associated with these variations before the manifestation of that feature. The most common clinical use of SNPs is to determine illness susceptibility and evaluate the success of pharmacological therapy tailored to an individual's need, as well as to identify disease susceptibility genes. These SNPs would able to be used as population screening markers for these three quantitative features and therefore crucial for improving human health and country's pharmaceutical condition in India. Perhaps with more research or a meta-analysis, new SNPs important to this will be uncovered. Finally, the outcome of our work may be used to locate common SNPs and genes across the genome that regulate these three quantitative traits.

\begin{abstract}
Abbreviations
AMPD3: Adenosine monophosphate deaminase 3; AZIN: Antizyme inhibitor; BDNF: Brain-derived neurotrophic factor; BMI: Body mass index; BP: Blood pressure; CAD: Coronary artery disease; $\mathrm{Cl}$ : Cognitive impairment; COMT: Catechol-o-methyl transferase; CVD: Cardiovascular disease; DBP: Diastolic blood pressure; FIQ: Functional intelligence quotient; FOXO3: Forkhead box O3; FSIQ: Full-scale intelligence quotient; GIPR: Gastric inhibitory polypeptide receptor; GWAS: Genome-wide association studies; GxE: Genotype-environmental interaction; HIP1: Huntingtin-interacting protein 1; HUFA: Highly unsaturated fatty acid; IQ: Intelligence quotient; MAP: Mean arterial pressure; PIQ: Performance intelligence quotient; PUFA: Polyunsaturated fatty acid; QTs: Quantitative traits; SBP: Systolic blood pressure; SLC: Solute carrier; SNP: Single nucleotide polymorphism; T2D: Type 2 diabetes; VAT: Visceral adipose tissue; VIQ: Verbal intelligence quotient; WC: Waist circumference.
\end{abstract}

\section{Acknowledgements}

The authors are grateful to the Chairman, Department of Zoology, AMU, Professor Mohammad Afzal for providing necessary laboratory facilities.

\section{Authors' contributions}

WC did conceptualization, data curation, investigation, methodology, writing - review, and formal analysis; RF did formal analysis, investigation, conceptualization and writing - review; AW did data curation, investigation and writing - review and editing; MA did conceptualization, methodology, investigation and supervision. All authors read and approved the final manuscript.

\section{Funding}

None.

Availability of data and materials Not applicable.

\section{Declarations}

Ethics approval and consent to participate

Not applicable.

Consent for publication

Not applicable.

\section{Competing interests}

The authors declare that they have no competing interests.

Received: 22 December 2021 Accepted: 21 February 2022

Published online: 08 March 2022

\section{References}

1. Alwi ZB (2005) The use of SNPs in pharmacogenomics studies. Malays J Med Sci MJMS 12(2):4-12

2. 1000 Genomes Project Consortium, Auton A, Brooks LD, Durbin RM, Garrison EP, Kang HM et al (2015) A global reference for human genetic variation. Nature 526(7571):68-74

3. Magner D, Biala E, Lisowiec-Wachnicka J, Kierzek E, Kierzek R (2015) A tandem oligonucleotide approach for SNP-selective RNA degradation using modified antisense oligonucleotides. PLoS ONE 10(11):e0142139

4. Khanna D, Yates Z (2019) Body Mass Index: A Critical Review Obesity. J Obes Weight Loss Ther 2:382

5. Ganuthula VRR, Sinha S (2019) The looking glass for intelligence quotient tests: the interplay of motivation, cognitive functioning, and affect. Front Psychol 10:2857

6. Oparil S, Acelajado MC, Bakris GL, Berlowitz DR, Cífková R, Dominiczak AF et al (2018) Hypertension. Nat Rev Dis Primer 22(4):18014

7. Chen R, Dharmarajan K, Kulkarni VT, Punnanithinont N, Gupta A, Bikdeli B et al (2013) Most important outcomes research papers on hypertension. Circ Cardiovasc Qual Outcomes 6(4):e26-35

8. Hossain FB, Adhikary G, Chowdhury AB, Shawon MSR (2019) Association between body mass index (BMI) and hypertension in south Asian population: evidence from nationally-representative surveys. Clin Hypertens 25(1):28

9. Landi F, Calvani R, Picca A, Tosato M, Martone AM, Ortolani E et al (2018) Body mass index is strongly associated with hypertension: results from the longevity check-up 7+ study. Nutrients 10(12):1976

10. Robertson JIS (2004) Childhood intelligence and blood pressure in middle age. J Hypertens 22(5):871

11. Lyngdoh T, Viswanathan B, Kobrosly R, van Wijngaarden E, Huber B, Davidson PW et al (2013) Blood pressure and cognitive function: a prospective analysis among adolescents in Seychelles. J Hypertens 31(6):1175-1182

12. Lande MB, Kupferman JC (2019) Blood pressure and cognitive function in children and adolescents. Hypertension 73(3):532-540

13. Sellier C, Campanari M, Julie Corbier C, Gaucherot A, Kolb-Cheynel I, Oulad-Abdelghani M et al (2016) Loss of C9 ORF 72 impairs autophagy and synergizes with polyQ Ataxin-2 to induce motor neuron dysfunction and cell death. EMBO J 35(12):1276-1297

14. Figueroa KP, Farooqi S, Harrup K, Frank J, O'Rahilly S, Pulst SM (2009) Genetic variance in the spinocerebellar ataxia type 2 (ATXN2) gene in children with severe early onset obesity. PLOS ONE 4(12):e8280

15. Halbach MV, Gispert S, Stehning T, Damrath E, Walter M, Auburger G (2017) Atxn2 knockout and CAG42-knock-in cerebellum shows similarly dysregulated expression in calcium homeostasis pathway. Cerebellum 16(1):68-81

16. Meierhofer D, Halbach M, Şen NE, Gispert S, Auburger G (2016) Ataxin-2 (Atxn2)-knock-out mice show branched chain amino acids and fatty acids pathway alterations. Mol Cell Proteom 15(5):1728-1739

17. Lv W-Q, Zhang X, Zhang Q, He J-Y, Liu H-M, Xia X et al (2017) Novel common variants associated with body mass index and coronary artery 
disease detected using a pleiotropic cFDR method. J Mol Cell Cardiol 112:1-7

18. Miyawaki K, Yamada Y, Yano H, Niwa H, Ban N, Ihara Y et al (1999) Glucose intolerance caused by a defect in the entero-insular axis: a study in gastric inhibitory polypeptide receptor knockout mice. Proc Natl Acad Sci 96(26):14843-14847

19. Gong J, Nishimura KK, Fernandez-Rhodes L, Haessler J, Bien S, Graff M et al (2018) Trans-ethnic analysis of metabochip data identifies two new loci associated with BMI. Int J Obes 42(3):384-390

20. Abadi A, Alyass A, Robiou du Pont S, Bolker B, Singh P, Mohan V et al (2017) Penetrance of polygenic obesity susceptibility loci across the body mass index distribution. Am J Hum Genet 101 (6):925-938

21. Graff M, Scott RA, Justice AE, Young KL, Feitosa MF, Barata L et al (2017) Genome-wide physical activity interactions in adiposity - a metaanalysis of 200,452 adults. PLoS Genet 13(4):e1006528

22. Heid IM, Vollmert C, Kronenberg F, Huth C, Ankerst DP, Luchner A et al (2008) Association of the MC4R V103I polymorphism with the metabolic syndrome: the KORA study. Obes Silver Spring Md 16(2):369-376

23. Vimaleswaran KS, Li S, Zhao JH, Luan J, Bingham SA, Khaw K-T et al (2009) Physical activity attenuates the body mass index-increasing influence of genetic variation in the FTO gene. Am J Clin Nutr 90(2):425-428

24. Hinney A, Nguyen TT, Scherag A, Friedel S, Brönner G, Müller TD et al (2007) Genome wide association (GWA) study for early onset extreme obesity supports the role of fat mass and obesity associated gene (FTO) variants. PLOS ONE 2(12):e1361

25. Marcadenti A, Fuchs FD, Matte U, Sperb F, Moreira LB, Fuchs SC (2013) Effects of FTO RS9939906 and MC4R RS17782313 on obesity, type 2 diabetes mellitus and blood pressure in patients with hypertension. Cardiovasc Diabetol 12(12):103

26. Speliotes EK, Willer CJ, Berndt SI, Monda KL, Thorleifsson G, Jackson AU et al (2010) Association analyses of 249,796 individuals reveal 18 new loci associated with body mass index. Nat Genet 42(11):937-948

27. Yu K, Li L, Zhang L, Guo L, Wang C (2020) Association between MC4R rs17782313 genotype and obesity: a meta-analysis. Gene 733:144372

28. Siffert W (2003) G-protein $\beta 3$ subunit 825T allele and hypertension. Curr Hypertens Rep 5(1):47-53

29. Caspi A, Williams B, Kim-Cohen J, Craig IW, Milne BJ, Poulton R et al (2007) Moderation of breastfeeding effects on the IQ by genetic variation in fatty acid metabolism. Proc Natl Acad Sci USA 104(47):18860-18865

30. Cannone V, Cefalu'AB, Noto D, Scott CG, Bailey KR, Cavera G et al (2013) The atrial natriuretic peptide genetic variant rs5068 is associated with a favorable cardiometabolic phenotype in a Mediterranean population. Diabetes Care 36(9):2850-2856

31. Zhang H, Mo X, Zhou Z, Zhu Z, Huangfu X, Xu T et al (2018) Smoking modifies the effect of two independent SNPs rs5063 and rs 198358 of NPPA on central obesity in the Chinese Han population. J Genet 97(4):987-994

32. de la Garza Puentes A, Montes Goyanes R, Chisaguano Tonato AM, Torres-Espínola FJ, Arias García M, de Almeida L et al (2017) Association of maternal weight with FADS and ELOVL genetic variants and fatty acid levels-The PREOBE follow-up. PLOS ONE 12(6):35

33. Zobel DP, Andreasen CH, Grarup N, Eiberg H, Sørensen TIA, Sandbaek A et al (2009) Variants near MC4R are associated with obesity and influence obesity-related quantitative traits in a population of middle-aged people: studies of 14,940 Danes. Diabetes 58(3):757-764

34. Sung YJ, Pérusse L, Sarzynski MA, Fornage M, Sidney S, Sternfeld B et al (2016) Genome-wide association studies suggest sex-specific loci associated with abdominal and visceral fat. Int J Obes 40(4):662-674

35. Johansson A, Marroni F, Hayward C, Franklin CS, Kirichenko AV, Jonasson I et al (2010) Linkage and genome-wide association analysis of obesityrelated phenotypes: association of weight with the MGAT1 gene. Obes Silver Spring Md 18(4):803-808

36. Widén E, Ripatti S, Cousminer DL, Surakka I, Lappalainen T, Järvelin M-R et al (2010) Distinct variants at LIN28B influence growth in height from birth to adulthood. Am J Hum Genet 86(5):773-782

37. Hunt SC, Stone S, Xin Y, Scherer CA, Magness CL, ladonato SP et al (2008) Association of the FTO gene with BMI. Obes Silver Spring Md 16(4):902-904
38. Jacobsson JA, Rask-Andersen M, Risérus U, Moschonis G, Koumpitski A, Chrousos GP et al (2012) Genetic variants near the MGAT1 gene are associated with body weight, BMl and fatty acid metabolism among adults and children. Int J Obes 36(1):119-129

39. Iwase M, Matsuo K, Nakatochi M, Oze I, Ito H, Koyanagi Y et al (2021) Differential effect of polymorphisms on body mass index across the life course of Japanese: the Japan multi-institutional collaborative cohort study. J Epidemiol 31(3):172-179

40. Corella D, Lai C-Q, Demissie S, Cupples LA, Manning AK, Tucker KL et al (2007) APOA5 gene variation modulates the effects of dietary fat intake on body mass index and obesity risk in the Framingham Heart Study. J Mol Med Berl Ger 85(2):119-128

41. Wang T, Moon J-Y, Wu Y, Amos Cl, Hung RJ, Tardon A et al (2017) Pleiotropy of genetic variants on obesity and smoking phenotypes: results from the Oncoarray Project of The International Lung Cancer Consortium. PLoS ONE 12(9):e0185660

42. Kamura Y, Iwata M, Maeda S, Shinmura S, Koshimizu Y, Honoki H et al (2016) FTO gene polymorphism is associated with type 2 diabetes through its effect on increasing the maximum BMI in Japanese men. PLoS ONE 11(11):e0165523

43. Laber S, Cox RD (2015) Commentary: FTO obesity variant circuitry and adipocyte browning in humans. Front Genet 6:318

44. Wen W, Zheng W, Okada Y, Takeuchi F, Tabara Y, Hwang J-Y et al (2014) Meta-analysis of genome-wide association studies in East Asian-ancestry populations identifies four new loci for body mass index. Hum Mol Genet 23(20):5492-5504

45. Liu Y, Liu Z, Song Y, Zhou D, Zhang D, Zhao T et al (2010) Meta-analysis added power to identify variants in FTO associated with type 2 diabetes and obesity in the Asian population. Obes Silver Spring Md 18(8):1619-1624

46. Fawcett KA, Barroso I (2010) The genetics of obesity: FTO leads the way. Trends Genet TIG 26(6):266-274

47. Wang N, Lu M, Chen C, Xia F, Han B, Li Q et al (2018) Adiposity genetic risk score modifies the association between blood lead level and body mass index. J Clin Endocrinol Metab 103(11):4005-4013

48. Han L, Tang L, Wang C, Chen Z, Zhang T, Chen S et al (2014) Fat mass and obesity-associated gene rs 11642015 polymorphism is significantly associated with prediabetes and type 2 diabetes subsequent to adjustment for body mass index. Biomed Rep 2(5):681-686

49. Fu J, Li G, Li L, Yin J, Cheng H, Han L et al (2017) The role of established East Asian obesity-related loci on pediatric leptin levels highlights a neuronal influence on body weight regulation in Chinese children and adolescents: the BCAMS study. Oncotarget 8(55):93593-93607

50. Bayoglu B, Yuksel H, Cakmak HA, Dirican A, Cengiz M (2016) Polymorphisms in the long non-coding RNA CDKN2B-AS1 may contribute to higher systolic blood pressure levels in hypertensive patients. Clin Biochem 49(10-11):821-827

51. Mitchell JA, Hakonarson H, Rebbeck TR, Grant SFA (2013) Obesity-susceptibility loci and the tails of the pediatric BMI distribution. Obes Silver Spring Md 21(6):1256-1260

52. Ruiz-Narváez EA, Haddad SA, Rosenberg L, Palmer JR (2016) Birth weight modifies the association between central nervous system gene variation and adult body mass index. J Hum Genet 61(3):193-198

53. Ibáñez-Zamacona ME, Poveda A, Rebato E (2019) Contribution of obesity associated genetic variants to anthropometric somatotype components. Anthropol Anz Ber Uber Biol-Anthropol Lit 76(2):101-111

54. Xi B, Zhao X, Shen Y, Wu L, Hotta K, Hou D et al (2013) Associations of obesity susceptibility loci with hypertension in Chinese children. Int J Obes 37(7):926-930

55. Rode L, Nordestgaard BG, Weischer M, Bojesen SE (2014) Increased body mass index, elevated C-reactive protein, and short telomere length. J Clin Endocrinol Metab 99(9):E1671-1675

56. Ninomiya-Baba M, Matsuo J, Sasayama D, Hori H, Teraishi T, Ota M et al (2017) Association of body mass index-related single nucleotide polymorphisms with psychiatric disease and memory performance in a Japanese population. Acta Neuropsychiatr 29(5):299-308

57. Okada Y, Kubo M, Ohmiya H, Takahashi A, Kumasaka N, Hosono N et al (2012) Common variants at CDKAL1 and KLF9 are associated with body mass index in east Asian populations. Nat Genet 44(3):302-306 
58. Costa-Urrutia P, Abud C, Franco-Trecu V, Colistro V, Rodríguez-Arellano ME, Alvarez-Fariña R et al (2020) Effect of 15 BMl-associated polymorphisms, reported for Europeans, across ethnicities and degrees of Amerindian ancestry in Mexican children. Int J Mol Sci 21(2):E374

59. O'Donnell KJ, Glover V, Lahti J, Lahti M, Edgar RD, Räikkönen K et a (2017) Maternal prenatal anxiety and child COMT genotype predict working memory and symptoms of ADHD. PLOS ONE 12(6):e0177506

60. Secher A, Bukh J, Bock C, Koefoed P, Rasmussen HB, Werge T et al (2009) Antidepressive-drug-induced bodyweight gain is associated with polymorphisms in genes coding for COMT and TPH1. Int Clin Psychopharmacol 24(4):199-203

61. Xu J, Boström AE, Saeed M, Dubey RK, Waeber G, Vollenweider P et al (2017) A genetic variant in the catechol-O-methyl transferase (COMT) gene is related to age-dependent differences in the therapeutic effect of calcium-channel blockers. Medicine (Baltimore) 96(30):e7029

62. Hong KW, Oh B (2012) Recapitulation of genome-wide association studies on body mass index in the Korean population. Int J Obes 36(8):1127-1130

63. Rask-Andersen M, Jacobsson JA, Moschonis G, Ek AE, Chrousos GP, Marcus C et al (2012) The MAP2K5-linked SNP rs2241423 is associated with BMI and obesity in two cohorts of Swedish and Greek children. BMC Med Genet 17(13):36

64. Kitamoto A, Kitamoto T, Mizusawa S, Teranishi H, So R, Matsuo T et al (2013) NUDT3 rs206936 is associated with body mass index in obese Japanese women. Endocr J 60(8):991-1000

65. Fedorowski A, Franceschini N, Brody J, Liu C, Verwoert GC, Boerwinkle E et al (2012) Orthostatic hypotension and novel blood pressureassociated gene variants: genetics of postural hemodynamics (GPH) Consortium. Eur Heart J 33(18):2331-2341

66. Kato N, Takeuchi F, Tabara Y, Kelly TN, Go MJ, Sim X et al (2011) Metaanalysis of genome-wide association studies identifies common variants associated with blood pressure variation in east Asians. Nat Genet 43(6):531-538

67. Bulayeva K, Lesch K-P, Bulayev O, Walsh C, Glatt S, Gurgenova F et al (2015) Genomic structural variants are linked with intellectual disability. J Neural Transm 122(9):1289-1301

68. Benyamin B, Pourcain B, Davis OS, Davies G, Hansell NK, Brion M-JA et al (2014) Childhood intelligence is heritable, highly polygenic and associated with FNBP1L. Mol Psychiatry 19(2):253-258

69. Sniekers S, Stringer S, Watanabe K, Jansen PR, Coleman JRI, Krapohl E et al (2017) Genome-wide association meta-analysis of 78,308 individuals identifies new loci and genes influencing human intelligence. Nat Genet 49(7):1107-1112

70. Luciano M, Miyajima F, Lind PA, Bates TC, Horan M, Harris SE et al (2009) Variation in the dysbindin gene and normal cognitive function in three independent population samples. Genes Brain Behav 8(2):218-227

71. Pan Y, Wang K-S, Aragam N (2011) NTM and NR3C2 polymorphisms influencing intelligence: family-based association studies. Prog Neuropsychopharmacol Biol Psychiatry 35(1):154-160

72. Gosso MF, van Belzen M, de Geus EJC, Polderman JC, Heutink P, Boomsma Dl et al (2006) Association between the CHRM2 gene and intelligence in a sample of 304 Dutch families. Genes Brain Behav 5(8):577-584

73. Andrews SJ, Das D, Anstey KJ, Easteal S (2017) Association of AKAP6 and MIR2113 with cognitive performance in a population-based sample of older adults. Genes Brain Behav 16(4):472-478

74. Rietveld CA, Esko T, Davies G, Pers TH, Turley P, Benyamin B et al (2014) Common genetic variants associated with cognitive performance identified using the proxy-phenotype method. Proc Natl Acad Sci USA 111(38):13790-13794

75. Piffer D (2015) Estimating the genotypic intelligence of populations and assessing the impact of socioeconomic factors and migrations. The Winnower [Internet]. [cited 2021 Sep 21]; Available from: https://thewi nnower.com//papers/estimating-the-genotypic-intelligence-of-popul ations-and-assessing-the-impact-of-socioeconomic-factors-and-migra tions

76. Greenbaum L, Ravona-Springer R, Livny A, Shelly S, Sharvit-Ginon I, Ganmore l et al (2019) The CADM2 gene is associated with processing speed performance-evidence among elderly with type 2 diabetes. World J Biol Psychiatry Off J World Fed Soc Biol Psychiatry 20(7):577-583
77. Zinkstok JR, de Wilde O, van Amelsvoort TAMJ, Tanck MW, Baas F, Linszen DH (2007) Association between the DTNBP1 gene and intelligence: a case-control study in young patients with schizophrenia and related disorders and unaffected siblings. Behav Brain Funct BBF 20(3):19

78. Dick DM, Aliev F, Kramer J, Wang JC, Hinrichs A, Bertelsen S et al (2007) Association of $\mathrm{CHRM} 2$ with IQ: converging evidence for a gene influencing intelligence. Behav Genet 37(2):265-272

79. Rolstad S, Pålsson E, Ekman CJ, Eriksson E, Sellgren C, Landén M (2015) Polymorphisms of dopamine pathway genes NRG1 and LMX1A are associated with cognitive performance in bipolar disorder. Bipolar Disord 17(8):859-868

80. Thomson PA, Harris SE, Starr JM, Whalley LJ, Porteous DJ, Deary IJ (2005) Association between genotype at an exonic SNP in DISC1 and normal cognitive aging. Neurosci Lett 389(1):41-45

81. Zhang S, Zhang J (2016) The association of DRD2 with insight problem solving. Front Psychol 7:1865

82. Milnik A, Heck A, Vogler C, Heinze H-J, de Quervain DJ-F, Papassotiropoulos A (2012) Association of KIBRA with episodic and working memory: a meta-analysis. Am J Med Genet Part B Neuropsychiatr Genet Off Publ Int Soc Psychiatr Genet 159B(8):958-969

83. Schneider A, Huentelman MJ, Kremerskothen J, Duning K, Spoelgen R, Nikolich K (2010) KIBRA: A new gateway to learning and memory? Front Aging Neurosci 2:4

84. Gosso MF, de Geus EJC, Polderman TJC, Boomsma DI, Heutink P, Posthuma D (2008) Common variants underlying cognitive ability: further evidence for association between the SNAP-25 gene and cognition using a family-based study in two independent Dutch cohorts. Genes Brain Behav 7(3):355-364

85. McHughen SA, Rodriguez PF, Kleim JA, Kleim ED, Marchal Crespo L, Procaccio $V$ et al (2010) BDNF val66met polymorphism influences motor system function in the human brain. Cereb Cortex 20(5):1254-1262

86. Hashimoto R, Noguchi H, Hori H, Ohi K, Yasuda Y, Takeda M et al (2009) Association between the dysbindin gene (DTNBP1) and cognitive functions in Japanese subjects. Psychiatry Clin Neurosci 63(4):550-556

87. Gosso MF, de Geus EJC, van Belzen MJ, Polderman TJC, Heutink P, Boomsma DI et al (2006) The SNAP-25 gene is associated with cognitive ability: evidence from a family-based study in two independent Dutch cohorts. Mol Psychiatry 11(9):878-886

88. Kuningas M, Putters M, Westendorp RGJ, Slagboom PE, van Heemst D (2007) SIRT1 gene, age-related diseases, and mortality: the Leiden 85-plus study. J Gerontol A Biol Sci Med Sci 62(9):960-965

89. Rietveld CA, Medland SE, Derringer J, Yang J, Esko T, Martin NW et al (2013) GWAS of 126,559 individuals identifies genetic variants associated with educational attainment. Science 340(6139):1467-1471

90. Zhang J-P, Burdick KE, Lencz T, Malhotra AK (2010) Meta-analysis of genetic variation in DTNBP1 and general cognitive ability. Biol Psychiatry 68(12):1126-1133

91. Gosso FM, de Geus EJC, Polderman TJC, Boomsma DI, Posthuma D, Heutink P (2007) Exploring the functional role of the CHRM2 gene in human cognition: results from a dense genotyping and brain expression study. BMC Med Genet 8(8):66

92. Smajlagić D, Kvarme Jacobsen K, Myrum C, Haavik J, Johansson S, Zayats $T$ (2018) Moderating effect of mode of delivery on the genetics of intelligence: explorative genome-wide analyses in ALSPAC. Brain Behav 8(12):e01144

93. Davies G, Armstrong N, Bis JC, Bressler J, Chouraki V, Giddaluru S et al (2015) Genetic contributions to variation in general cognitive function: a meta-analysis of genome-wide association studies in the CHARGE consortium (N=53949). Mol Psychiatry 20(2):183-192

94. Zabaneh D, Krapohl E, Gaspar HA, Curtis C, Lee SH, Patel H et al (2018) A genome-wide association study for extremely high intelligence. Mol Psychiatry 23(5):1226-1232

95. Houlihan LM, Harris SE, Luciano M, Gow AJ, Starr JM, Visscher PM et al (2009) Replication study of candidate genes for cognitive abilities: the Lothian Birth Cohort 1936. Genes Brain Behav 8(2):238-247

96. Wahlberg KE, Guazzetti S, Pineda D, Larsson SC, Fedrighi C, Cagna G et al (2018) Polymorphisms in manganese transporters SLC30A10 and SLC39A8 are associated with children's neurodevelopment by influencing manganese homeostasis. Front Genet 9:664 
97. Hagman J, Belanger C, Travis A, Turck CW, Grosschedl R (1993) Cloning and functional characterization of early B-cell factor, a regulator of lymphocyte-specific gene expression. Genes Dev 7(5):760-773

98. LifeLines Cohort Study, EchoGen consortium, AortaGen Consortium, CHARGE Consortium Heart Failure Working Group, KidneyGen consortium, CKDGen consortium et al (2011) Genome-wide association study identifies six new loci influencing pulse pressure and mean arterial pressure. Nat Genet 43(10):1005-1011

99. Binici J, Koch J (2014) BAG-6, a jack of all trades in health and disease. Cell Mol Life Sci 71(10):1829-1837

100. Rasila T, Lehtonen A, Kanerva K, Mäkitie LT, Haglund C, Andersson LC (2016) Expression of ODC antizyme inhibitor 2 (AZIN2) in human secretory cells and tissues. PLoS ONE 11(3):e0151175

101. Kelly TN, Rice TK, Gu D, Hixson JE, Chen J, Liu D et al (2009) Novel genetic variants in the $\alpha$-adducin and guanine nucleotide binding protein $\beta$-polypeptide 3 genes and salt sensitivity of blood pressure. Am J Hypertens 22(9):985-992

102. Dahlberg J, Nilsson L-O, von Wowern F, Melander O (2007) Polymorphism in NEDD4L Is associated with increased salt sensitivity, reduced levels of P-renin and increased levels of Nt-proANP. PLOS ONE 2(5):e432

103. Fava C, von Wowern F, Berglund G, Carlson J, Hedblad B, Rosberg L et al (2006) 24-h ambulatory blood pressure is linked to chromosome 18q21-22 and genetic variation of NEDD4L associates with cross-sectional and longitudinal blood pressure in Swedes. Kidney Int 70(3):562-569

104. Kato N, Miyata T, Tabara Y, Katsuya T, Yanai K, Hanada H et al (2008) High-density association study and nomination of susceptibility genes for hypertension in the Japanese National Project. Hum Mol Genet 17(4):617-627

105. Lule SA, Mentzer AJ, Namara B, Muwenzi AG, Nassanga B, kizito D et al (2019) A genome-wide association and replication study of blood pressure in Ugandan early adolescents. Mol Genet Genomic Med. 2019 Oct [cited 2021 Oct 2];7(10). Available from: https://onlinelibrary.wiley.com/ doi/https://doi.org/10.1002/mgg3.950

106. Vázquez-Moreno M, Locia-Morales D, Peralta-Romero J, Sharma T, Meyre D, Cruz M et al (2021) AGT rs4762 is associated with diastolic blood pressure in Mexicans with diabetic nephropathy. J Diabetes Complicat 35(3):107826

107. Soltész B, Pikó P, Sándor J, Kósa Z, Ádány R, Fiatal S (2020) The genetic risk for hypertension is lower among the Hungarian Roma population compared to the general population. PLoS ONE 15(6):e0234547

108. Fung MM, Nguyen C, Mehtani P, Salem RM, Perez B, Thomas B et al (2008) Genetic variation within adrenergic pathways determines in vivo effects of presynaptic stimulation in humans. Circulation 117(4):517-525

109. Thomsen LCV, McCarthy NS, Melton PE, Cadby G, Austgulen R, Nygård OK et al (2017) The antihypertensive MTHFR gene polymorphism rs 17367504-G is a possible novel protective locus for preeclampsia. J Hypertens 35(1):132-139

110. Musso G, Saba F, Cassader M, Paschetta E, De Michieli F, Pinach S et al (2019) Angiotensin II type 1 receptor rs5186 gene variant predicts incident NAFLD and associated hypertension: role of dietary fat-induced pro-inflammatory cell activation. Am J Gastroenterol 114(4):607-619

111. Kundu A, Anand A (2013) Computational study of ADD1 gene polymorphism associated with hypertension. Cell Biochem Biophys 65(1):13-19

112. Ren M, Ng FL, Warren HR, Witkowska K, Baron M, Jia Z et al (2018) The biological impact of blood pressure-associated genetic variants in the natriuretic peptide receptor $\mathrm{C}$ gene on human vascular smooth muscle. Hum Mol Genet 27(1):199-210

113. Gamil S, Erdmann J, Abdalrahman IB, Mohamed AO (2017) Association of NOS3 gene polymorphisms with essential hypertension in Sudanese patients: a case control study. BMC Med Genet 18(1):128

114. Azam AB, Azizan EAB (2018) Brief overview of a decade of genomewide association studies on primary hypertension. Int J Endocrinol 2018:7259704

115. Lardjam-Hetraf SA, Mediene-Benchekor S, Ouhaibi-Djellouli H, Meroufel DN, Boulenouar H, Hermant X et al (2015) Effects of established blood pressure loci on blood pressure values and hypertension risk in an Algerian population sample. J Hum Hypertens 29(5):296-302

116. Padmanabhan S, Melander O, Johnson T, Di Blasio AM, Lee WK, Gentilini D et al (2010) Genome-wide association study of blood pressure extremes identifies variant near UMOD associated with hypertension. PLoS Genet 6(10):e1001177

117. Hong GL, Chen XZ, Liu Y, Liu YH, Fu X, Lin SB et al (2013) Genetic variations in MOV10 and CACNB2 are associated with hypertension in a Chinese Han population. Genet Mol Res 12(4):6220-6227

118. Levy D, Ehret GB, Rice K, Verwoert GC, Launer LJ, Dehghan A et al (2009) Genome-wide association study of blood pressure and hypertension. Nat Genet 41(6):677-687

119. International Consortium for Blood Pressure Genome-Wide Association Studies, Ehret GB, Munroe PB, Rice KM, Bochud M, Johnson AD et al (2011) Genetic variants in novel pathways influence blood pressure and cardiovascular disease risk. Nature 478(7367):103-109

120. Chen Y-L, Li T-J, Hao Y, Wu B-G, Li H, Geng N et al (2018) Association of rs2271037 and rs3749585 polymorphisms in CORIN with susceptibility to hypertension in a Chinese Han population: a case-control study. Gene 20(651):79-85

121. Nossent AY, Hansen JL, Doggen C, Quax PHA, Sheikh SP, Rosendaal FR (2011) SNPs in microRNA binding sites in 3'-UTRs of RAAS genes influence arterial blood pressure and risk of myocardial infarction. Am J Hypertens 24(9):999-1006

122. Maher BS, Vladimirov VI, Latendresse SJ, Thiselton DL, McNamee R, Kang $M$ et al (2011) The AVPR1A gene and substance use disorders: association, replication, and functional evidence. Biol Psychiatry 70(6):519-527

123. Fu X, Guo L, Jiang Z-M, Zhao L-S, Xu A-G (2014) An miR-143 promoter variant associated with essential hypertension. Int J Clin Exp Med 7(7):1813-1817

124. Hanin G, Shenhar-Tsarfaty S, Yayon N, Yau YH, Hoe YY, Bennett ER et al (2014) Competing targets of microRNA-608 affect anxiety and hypertension. Hum Mol Genet 23(17):4569-4580

125. Lin W-J, Salton SR (2013) The regulated secretory pathway and human disease: insights from gene variants and single nucleotide polymorphisms. Front Endocrinol 4:96

126. Kayima J, Liang J, Natanzon Y, Nankabirwa J, Ssinabulya I, Nakibuuka J et al (2017) Association of genetic variation with blood pressure traits among East Africans. Clin Genet 92(5):487-494

127. Zhang R, Witkowska K, Afonso Guerra-Assunção J, Ren M, Ng FL, Mauro C et al (2016) A blood pressure-associated variant of the SLC39A8 gene influences cellular cadmium accumulation and toxicity. Hum Mol Genet 25(18):4117-4126

128. Zhong L-L, Ding L-S, He W, Tian X-Y, Cao H, Song Y-Q et al (2017) Systolic hypertension related single nucleotide polymorphism is associated with susceptibility of ischemic stroke. Eur Rev Med Pharmacol Sci 21(12):2901-2906

129. Hong K-W, Jin H-S, Lim J-E, Kim S, Go MJ, Oh B (2010) Recapitulation of two genomewide association studies on blood pressure and essential hypertension in the Korean population. J Hum Genet 55(6):336-341

130. Lin Y, Lai X, Chen B, Xu Y, Huang B, Chen Z et al (2011) Genetic variations in CYP17A1, CACNB2 and PLEKHA7 are associated with blood pressure and/or hypertension in She ethnic minority of China. Atherosclerosis 219(2):709-714

131. Wahlstrand B, Orho-Melander M, Delling L, Kjeldsen S, Narkiewicz K, Almgren P et al (2009) The myocardial infarction associated CDKN2A/ CDKN2B locus on chromosome 9p21 is associated with stroke independently of coronary events in patients with hypertension. J Hypertens 27(4):769-773

132. Newton-Cheh C, Larson MG, Vasan RS, Levy D, Bloch KD, Surti A et al (2009) Association of common variants in NPPA and NPPB with circulating natriuretic peptides and blood pressure. Nat Genet 41(3):348-353

133. Tabara Y, Kohara K, Kita Y, Hirawa N, Katsuya T, Ohkubo T et al (2010) Common variants in the ATP2B1 gene are associated with susceptibility to hypertension: the Japanese Millennium Genome Project. Hypertens Dallas Tex 56(5):973-980

134. Hong K-W, Jin H-S, Lim J-E, Cho YS, Go MJ, Jung J et al (2010) Nonsynonymous single-nucleotide polymorphisms associated with blood pressure and hypertension. J Hum Hypertens 24(11):763-774

135. Hong K-W, Go MJ, Jin H-S, Lim J-E, Lee J-Y, Han BG et al (2010) Genetic variations in ATP2B1, CSK, ARSG and CSMD1 loci are related to blood pressure and/or hypertension in two Korean cohorts. J Hum Hypertens 24(6):367-372

136. Sun D, Zhou T, Heianza Y, Li X, Fan M, Fonseca VA et al (2019) Type 2 diabetes and hypertension. Circ Res 124(6):930-937 
137. Qu Y-L, Wu C-M, Zhang L-X, Wen B-L, Zhang X, Ma C et al (2016) Association between alpha-adducin gene rs4963 polymorphism and hypertension risk in Asian population: a meta-analysis. Cell Mol Biol Noisy Gd Fr 62(13):62-64

138. Lu X, Wang L, Lin X, Huang J, Charles GC, He M et al (2015) Genomewide association study in Chinese identifies novel loci for blood pressure and hypertension. Hum Mol Genet 24(3):865-874

139. Shen G-Q, Li L, Rao S, Abdullah KG, Ban JM, Lee B-S et al (2008) Four SNPs on chromosome 9p21 in a South Korean population implicate a genetic locus that confers high cross-race risk for development of coronary artery disease. Arterioscler Thromb Vasc Biol 28(2):360-365

140. Smith JG, Melander O, Lövkvist H, Hedblad B, Engström G, Nilsson P et al (2009) Common genetic variants on chromosome 9p21 confers risk of ischemic stroke: a large-scale genetic association study. Circ Cardiovasc Genet 2(2):159-164

141. Lin H-F, Tsai P-C, Lin R-T, Khor G-T, Sheu S-H, Juo S-HH (2010) Sex differential genetic effect of chromosome 9p21 on subclinical atherosclerosis. PLoS ONE 5(11):e15124

142. Siffert W, Forster $P$, Jöckel K-H, Mvere DA, Brinkmann B, Naber C et al (1999) Worldwide ethnic distribution of the $G$ protein $\beta 3$ subunit 8257 allele and its association with obesity in Caucasian, Chinese, and Black African individuals. J Am Soc Nephrol 10(9):1921-1930

143. Stender S, Nordestgaard BG, Tybjaerg-Hansen A (2013) Elevated body mass index as a causal risk factor for symptomatic gallstone disease: a Mendelian randomization study. Hepatology 58(6):2133-2141

144. Zhao J, Bradfield JP, Li M, Wang K, Zhang H, Kim CE et al (2009) The role of obesity-associated loci identified in genome-wide association studies in the determination of pediatric BMI. Obesity 17(12):2254-2257

145. Wang Y, Zhang Y, Zhang J, Tang X, Qian Y, Gao P et al (2013) Association of a functional single-nucleotide polymorphism in the ALDH2 gene with essential hypertension depends on drinking behavior in a Chinese Han population. J Hum Hypertens 27(3):181-186

146. Hasi T, Hao L, Yang L, Su XL (2011) Acetaldehyde dehydrogenase 2 SNP rs671 and susceptibility to essential hypertension in Mongolians: a case control study. Genet Mol Res 10(1):537-543

147. Li Z-M, Kong C-Y, Sun K-Y, Wang L-S (2017) The ALDH2 gene rs671 polymorphism is not associated with essential hypertension. Clin Exp Hypertens 39(8):691-695

148. Niu W, Zhang Y, Ji K, Gu M, Gao P, Zhu D (2010) Confirmation of top polymorphisms in hypertension genome wide association study among Han Chinese. Clin Chim Acta 411(19-20):1491-1495

149. Abdullah A, Peeters A, de Courten M, Stoelwinder J (2010) The magnitude of association between overweight and obesity and the risk of diabetes: a meta-analysis of prospective cohort studies. Diabetes Res Clin Pract 89(3):309-319

150. Poirier P, Giles TD, Bray GA, Hong Y, Stern JS, Pi-Sunyer FX et al (2006) Obesity and cardiovascular disease: pathophysiology, evaluation, and effect of weight loss: an update of the 1997 American Heart Association Scientific Statement on Obesity and Heart Disease From the Obesity Committee of the Council on Nutrition, Physical Activity, and Metabolism. Circulation 113(6):898-918

151. Lavie CJ, Milani RV, Ventura HO (2009) Obesity and cardiovascular disease. J Am Coll Cardiol 53(21):1925-1932

152. Sabia S, Kivimaki M, Shipley MJ, Marmot MG, Singh-Manoux A (2009) Body mass index over the adult life course and cognition in late midlife: the Whitehall II Cohort Study. Am J Clin Nutr 89(2):601-607

153. Ward MA, Carlsson CM, Trivedi MA, Sager MA, Johnson SC (2005) The effect of body mass index on global brain volume in middle-aged adults: a cross sectional study. BMC Neurol 5(1):23

154. Groen-Blokhuis MM, Franić S, van Beijsterveldt CEM, de Geus E, Bartels M, Davies GE et al (2013) A prospective study of the effects of breastfeeding and FADS2 polymorphisms on cognition and hyperactivity/attention problems. Am J Med Genet B Neuropsychiatr Genet 162(5):457-465

155. Hartwig FP, Davies NM, Horta BL, Victora CG, Davey Smith G (2016) Effect modification of FADS2 polymorphisms on the association between breastfeeding and intelligence: protocol for a collaborative meta-analysis. BMJ Open 6(6):e010067

156. Ge L, Gordon JS, Hsuan C, Stenn K, Prouty SM (2003) Identification of the $\Delta-6$ desaturase of human sebaceous glands: expression and enzyme activity. J Investig Dermatol 120(5):707-714
157. Stein DJ, Newman TK, Savitz J, Ramesar R (2006) Warriors versus worriers: the role of COMT gene variants. CNS Spectr 11(10):745-748

158. Ancín I, Cabranes JA, Vázquez-Álvarez B, Santos JL, Sánchez-Morla E, García-Jiménez MÁ et al (2011) Sensory gating deficit is associated with catechol-O-methyltransferase polymorphisms in bipolar disorder. World J Biol Psychiatry 12(5):376-384

159. Gupta M, Chauhan C, Bhatnagar P, Gupta S, Grover S, Singh PK et al (2009) Genetic susceptibility to schizophrenia: role of dopaminergic pathway gene polymorphisms. Pharmacogenomics 10(2):277-291

160. Prata DP, Mechelli A, Fu CHY, Picchioni M, Kane F, Kalidindi S et al (2009) Opposite effects of catechol-O-methyltransferase Val158Met on cortical function in healthy subjects and patients with schizophrenia. Biol Psychiatry 65(6):473-480

161. Shibata N, Nagata T, Tagai K, Shinagawa S, Ohnuma T, Kawai E et al (2015) Association between the catechol-O-methyltransferase polymorphism Val158Met and Alzheimer's disease in a Japanese population: COMT polymorphism and Alzheimer's disease. Int J Geriatr Psychiatry 30(9):927-933

162. Michaelovsky E, Gothelf D, Korostishevsky M, Frisch A, Burg M, Carmel M et al (2008) Association between a common haplotype in the COMT gene region and psychiatric disorders in individuals with 22q11.2DS. Int J Neuropsychopharmacol. https://doi.org/10.1017/S1461145707008085

163. Kring SII, Werge T, Holst C, Toubro S, Astrup A, Hansen T et al (2009) Polymorphisms of serotonin receptor $2 \mathrm{~A}$ and $2 \mathrm{C}$ genes and COMT in relation to obesity and type 2 diabetes. PLoS ONE 4(8):e6696

164. CHARGE Cognitive Working Group, Marioni RE, Yang J, Dykiert D, Mõttus R, Campbell A et al (2016) Assessing the genetic overlap between BMI and cognitive function. Mol Psychiatry 21(10):1477-1482

165. Strachan MWJ, Reynolds RM, Marioni RE, Price JF (2011) Cognitive function, dementia and type 2 diabetes mellitus in the elderly. Nat Rev Endocrinol 7(2):108-114

166. Mõttus R, Luciano M, Starr JM, Deary IJ (2013) Diabetes and life-long cognitive ability. J Psychosom Res 75(3):275-278

167. Qizilbash N, Gregson J, Johnson ME, Pearce N, Douglas I, Wing K et al (2015) BMI and risk of dementia in two million people over two decades: a retrospective cohort study. Lancet Diabetes Endocrinol 3(6):431-436

168. Elias MF, Goodell AL, Dore GA (2012) Hypertension and cognitive functioning: a perspective in historical context. Hypertension 60(2):260-268

169. Sharma M, Kupferman JC, Brosgol Y, Paterno K, Goodman S, Prohovnik I et al (2010) The effects of hypertension on the paediatric brain: a justifiable concern. Lancet Neurol 9(9):933-940

170. Novak V, Hajjar I (2010) The relationship between blood pressure and cognitive function. Nat Rev Cardiol 7(12):686-698

171. Toth P, Tarantini S, Csiszar A, Ungvari Z (2017) Functional vascular contributions to cognitive impairment and dementia: mechanisms and consequences of cerebral autoregulatory dysfunction, endothelial impairment, and neurovascular uncoupling in aging. Am J PhysiolHeart Circ Physiol 312(1):H1-20

172. Chen Y-C, Liu Y-L, Tsai S-J, Kuo P-H, Huang S-S, Lee Y-S (2019) LRRTM4 and PCSK5 genetic polymorphisms as markers for cognitive impairment in a hypotensive aging population: a genome-wide association study in Taiwan. J Clin Med 8(8):1124

173. Cotman CW, Berchtold NC (2002) Exercise: a behavioral intervention to enhance brain health and plasticity. Trends Neurosci 25(6):295-301

\section{Publisher's Note}

Springer Nature remains neutral with regard to jurisdictional claims in published maps and institutional affiliations. 